\title{
DEROCERAS PANORMITANUM AND CONGENERS FROM MALTA AND SICILY, WITH A REDESCRIPTION OF THE WIDESPREAD PEST SLUG AS DEROCERAS INVADENS N. SP.
}

\author{
Heike Reise*, John M. C. Hutchinson, Susann SChunack, Bettina SCHLitT
}

\author{
Senckenberg Museum of Natural History Görlitz, PF 300 154, D-02806 Görlitz, Germany \\ (Heike.Reise@senckenberg.de) \\ *corresponding author
}

\begin{abstract}
The name Deroceras panormitanum is generally applied to a terrestrial slug that has spread worldwide and can be a pest; earlier this tramp species had been called Deroceras caruanae. Neither name is appropriate. The taxonomic descriptions apply to a species from Sicily and Malta. This true D. panormitanum and the tramp species are distinct in morphology and mating behaviour. For instance, the penial caecum of $D$. panormitanum is more pointed, everting faster at copulation. The size of the penial lobe varies considerably in preserved specimens but is always prominent at copulation. D. panormitanum is distinct from the Maltese endemic Deroceras golcheri, but a phylogeny based on mtDNA COI sequences implies that they are more closely related than is the tramp species. D. golcheri has a still closer counterpart on Sicily, but we leave the taxonomy of this "species X" unresolved. In interspecific crosses, D. panormitanum may transfer sperm to the partner's sarcobelum whereas the partner fails to evert its penis (D. golcheri) or to transfer sperm (the tramp species). Names previously applied to the tramp species originally referred to D. panormitanum or are otherwise invalid, so it is here formally redescribed as D. invadens. Deroceras giustianum Wiktor, 1998 is synonymised with $D$. panormitanum.
\end{abstract}

KEY WORDS: simultaneous hermaphrodites, unilateral copulation, genital morphology, mating behaviour, COI mtDNA, cryptic species, reproductive isolation, terrestrial slugs, Agriolimacidae, Mediterranean

\section{INTRODUCTION}

This study was originally set up to investigate whether Deroceras golcheri (Altena, 1962) is a valid species different from the only other representative of the genus on Malta, Deroceras panormitanum (Lessona et Pollonera, 1882). Under the assumption that the natural distribution of $D$. panormitanum encompasses wide areas of the western Mediterranean, it has been considered as morphologically extremely variable (GIUSTI 1976, GIUSTI \& MANGANELLI 1990, WIKTOR 2000), so that $D$. golcheri might represent merely a morph of D. panormitanum (WIKTOR 2000). By using two new sets of characters (mating behaviour and mtDNA COI sequences), we here show that $D$. golcheri is distinct from $D$. panormitanum. More surprisingly, it turned out that the widespread invasive pest slug usually called $D$. panormitanum is also a different species.
We refer to this here as the "tramp species", but finally redescribe it as Deroceras invadens $\mathrm{n}$. sp.

The tramp species was first reported with certainty from England in 1930 (QUICK 1960) and was already established in California by 1940 (PILSBRY 1948). It is now known widely from western and central Europe, North and South America, South Africa, Australia, New Zealand and various oceanic islands (BARKER 1999, REISE et al. 2006). In central Europe its range is still expanding (WIKTOR 2001a, DVOŘÁK et al. 2003, HORSÁK \& DVOŘÁK 2003). REISE et al. (2006) briefly review its ecology (see also LEE et al. 2009).

The type locality of $D$. panormitanum is Palermo, Sicily (LESSONA \& POLLONERA 1882). A few years after the description of $D$. panormitanum, two other similar species were described: Deroceras pollonerae 
(Simroth, 1889), also from Palermo, and Deroceras caruanae (Pollonera, 1891) from Valletta on Malta. The descriptions did not consider similarities with $D$. panormitanum but nowadays these names are usually considered synonyms, following GIUSTI (1986), GIUSTI \& MANGANELLI (1990) and WIKTOR (2000), although these authors acknowledged that further re-

\section{MATERIAL AND METHODS}

\section{ANIMALS}

Table 1 lists the collecting sites of specimens from Malta, Sicily, Sardinia and England. In some cases, F1 and/or F2 offspring of wild-collected individuals were used for mating experiments. We used additional slugs of the tramp species for interspecific mating setups with Maltese D. panormitanum: Banstead (same site as E1 in Table 1), coll. JMCH, 19.2.2000-3.4.2000; Berchem, Antwerp (c. 51 $10^{\circ} 48^{\prime \prime} \mathrm{N}, 4^{\circ} 25^{\prime} 09^{\prime \prime E}$ ), coll. T. search was necessary. Our data will support these synonymisations. Other species have also been proposed as possible synonyms, because $D$. panormitanum had been considered so variable, but it appears much less variable once we recognise that the tramp species is distinct.

BACKELJAU, Feb. 2000. Other collections from site E1 were used for the species description of D. invadens and COI sequencing.

Additional preserved specimens for morphological analysis were generously provided by F. GIUSTI:

From Sicily: 1 from Milazzo, 2 samples $(4+4$ slugs $)$ from Palermo, Monte Pellegrino, 3 from Terrasini, 2 from Monte Inici, Pizzo Brando, 2 from Santa Ninfa, 3 from near Niscemi (at least the first 4 samples were D. panormitanum; the last sample was

Table 1. Collecting sites and species identities for slug samples used for the mating behaviour. Collections: M1-M2: T. BACKELJAU, 21.2.1994; M3-M9: JMCH \& HR, 12-17.2.2000; S1-S2: M. SARÀ, 25.10.2007; S3: E. BELliA, Nov. or Dec. 2007; S4: M. SARÀ, 11.11.2007; S5: BS and M. SCHLITT, 14.11.2010; S6: BS, 12.11.2010; S7-S9: J. ETZOLD, 15-19.3.2011, Sa1: HR \& JMCH, 17.10.2009; E1: JMCH, 5.2.2009. Species identities: P - D. panormitanum, G - D. golcheri, T - tramp species, $\mathrm{X}$ - species X

\begin{tabular}{|c|c|c|c|}
\hline Site No. & Collection Site & Latitude, longitude & Species \\
\hline \multicolumn{4}{|l|}{ Malta } \\
\hline M1 & Mosta, Wied il-Ghasel; F2 offspring & c. $35^{\circ} 54^{\prime} 47^{\prime \prime} \mathrm{N}, 14^{\circ} 25^{\prime} 29^{\prime \prime} \mathrm{E}$ & $\mathrm{P}$ \\
\hline M2 & Buskett carpark; F2 offspring & c. $35^{\circ} 51^{\prime} 33^{\prime \prime} \mathrm{N}, 14^{\circ} 23^{\prime} 53 " \mathrm{E}$ & $\mathrm{P}$ \\
\hline M3 & Buskett & $35^{\circ} 51^{\prime} 23 " \mathrm{~N}, 14^{\circ} 23^{\prime} 56^{\prime \prime} \mathrm{E}$ & $\mathrm{P}$ \\
\hline M4 & SW Floriana, Valletta & c. $35^{\circ} 53^{\prime} 29^{\prime \prime} \mathrm{N}, 14^{\circ} 30^{\prime} 14^{\prime \prime} \mathrm{E}$ & $\mathrm{P}$ \\
\hline M5 & Victoria-Masalforn Road, Gozo & $36^{\circ} 03^{\prime} \mathrm{N}, 14^{\circ} 15^{\prime} \mathrm{E}$ & $\mathrm{P}, \mathrm{G}$ \\
\hline M6 & Il Maqluba (type locality of $D$. golcheri) & $35^{\circ} 49^{\prime} 51.2^{\prime \prime N}, 14^{\circ} 27^{\prime} 26.3^{\prime \prime E}$ & $\mathrm{P}, \mathrm{G}$ \\
\hline M7 & SE of Inland Sea, Gozo & $36^{\circ} 03^{\prime} 04^{\prime \prime N}, 14^{\circ} 11^{\prime} 36^{\prime \prime E}$ & $\mathrm{P}, \mathrm{G}$ \\
\hline M8 & SW of Selmun Palace & $35^{\circ} 57^{\prime} 21 " \mathrm{~N}, 14^{\circ} 21^{\prime} 40^{\prime \prime} \mathrm{E}$ & G \\
\hline M9 & WSW of Fort Campbell & c. $35^{\circ} 57^{\prime} 45^{\prime \prime} \mathrm{N}, 14^{\circ} 23^{\prime} 09^{\prime \prime} \mathrm{E}$ & G \\
\hline \multicolumn{4}{|l|}{ Sicily } \\
\hline $\mathrm{S} 1$ & Near Bagheria; wild slugs + F1, F2 offspring & c. $38^{\circ} 04^{\prime} \mathrm{N}, 13^{\circ} 30^{\prime} \mathrm{E}$ & $\mathrm{P}$ \\
\hline S2 & Near Bagheria; wild slugs + F1 offspring & c. $38^{\circ} 04^{\prime} \mathrm{N}, 13^{\circ} 30^{\prime} \mathrm{E}$ & $\mathrm{P}$ \\
\hline S3 & Bagheria village, wild slugs $+\mathrm{F} 1$, F2 offspring & c. $38^{\circ} 04^{\prime} \mathrm{N}, 13^{\circ} 30^{\prime} \mathrm{E}$ & $\mathrm{P}$ \\
\hline $\mathrm{S} 4$ & Gratteri, wild slugs + F1 offspring & c. $37^{\circ} 57^{\prime} 57^{\prime \prime} \mathrm{N}, 13^{\circ} 58^{\prime} 26^{\prime \prime E}$ & $\mathrm{X}$ \\
\hline S5 & Near Agnone Bagni & $37^{\circ} 18^{\prime} 31^{\prime \prime} \mathrm{N}, 15^{\circ} 05^{\prime} 56^{\prime \prime} \mathrm{E}$ & $\mathrm{P}$ \\
\hline S6 & $9 \mathrm{~km} \mathrm{SE}$ of Palazzolo & $37^{\circ} 01^{\prime} 38^{\prime \prime} \mathrm{N}, 15^{\circ} 00^{\prime} 18^{\prime \prime} \mathrm{E}$ & $\mathrm{X}$ \\
\hline S7 & Taormina & $37^{\circ} 50^{\prime} 58.6^{\prime \prime} \mathrm{N}, 15^{\circ} 17^{\prime} 12.5^{\prime \prime E}$ & $\mathrm{P}$ \\
\hline S8 & Siracusa & $37^{\circ} 03^{\prime} 28.5^{\prime \prime} \mathrm{N}, 15^{\circ} 17^{\prime} 32.7^{\prime \prime E}$ & $\mathrm{P}$ \\
\hline S9 & Agrigento (on lettuce in market) & $37^{\circ} 18^{\prime} 34.3^{\prime \prime} \mathrm{N}, 13^{\circ} 35^{`} 12.5^{\prime \prime} \mathrm{E}$ & $\mathrm{T}$ \\
\hline \multicolumn{4}{|l|}{ Sardinia } \\
\hline Sa1 & Cala di Luna & $40^{\circ} 13^{\prime} 28^{\prime \prime} \mathrm{N}, 9^{\circ} 37^{\prime} 32^{\prime \prime} \mathrm{E}$ & $\mathrm{T}$ \\
\hline \multicolumn{4}{|l|}{ England } \\
\hline E1 & Nork Park, Banstead (type locality of D. invadens) & $51^{\circ} 18^{\prime} 53.1^{\prime \prime} \mathrm{N}, 0^{\circ} 13^{\prime} 22.4^{\prime \prime} \mathrm{W}$ & $\mathrm{T}$ \\
\hline
\end{tabular}




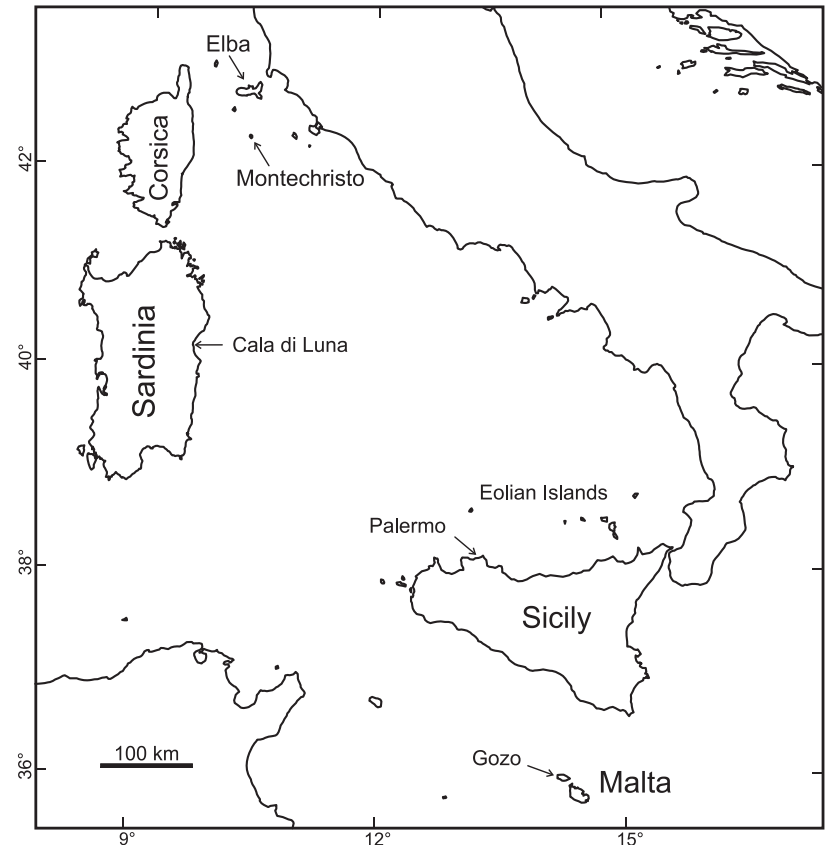

Fig. 1. Map of the central Mediterranean showing the boot of Italy and neighbouring islands mentioned in the text

reminiscent of species X - see Results section on morphology below).

From the Eolian Islands: 2 from Alicudi (Filo dell' Arpa), 4 from Panerea (Punta Peppe Maria) and 3 from Basiluzzo (Scoglio di Basiluzzo).

For detailed information about the specimens used for COI gene sequencing and GenBank accession numbers, see the caption of Figure 9. In addition to specimens from sites in Table 1, we sequenced further individuals of the tramp species: three from Germany, two from England, one from France, one from Canada, and one from the USA. We also included three specimens from Crete that were reminiscent of $D$. panormitanum: their genital anatomy agreed with the "D. cf. panormitanum" of WIKTOR (2001b), but was nevertheless different from Maltese and Sicilian $D$. panormitanum and from the tramp species.

We added all COI sequences of other Deroceras species available in GenBank: one unidentified, but unambiguous tramp-species sequence (from Marion Islands, a sub-Antarctic possession of South Africa; LEE et al. 2009), three D. laeve (O. F. Müller 1774) (USA and Taiwan), and four D. reticulatum (O. F. Müller 1774) (UK, USA and Taiwan).

\section{MORPHOLOGY}

Slugs were killed in carbonized water and preserved in $75 \%$ ethanol. Genital drawings were made using a camera lucida attached to a stereomicroscope. To study the use of genital organs during copulation, some Sicilian $D$. panormitanum couples were killed at different stages of mating using boiling water or an ice spray (CRAZE \& BARR 2002). They were then trans- ferred into $75 \%$ ethanol. One couple studied under a microscope before transfer into ethanol demonstrated that the fixation process caused little distortion.

\section{MATING BEHAVIOUR}

Slugs in the laboratory were normally kept in Petri dishes containing damp tissue paper, a fallen beech leaf, lettuce, rolled oats, carrot and, in later years, a cat food pellet. The contents were changed twice a week. Dishes were kept at $15-17^{\circ} \mathrm{C}$ with a regular day-night light cycle. Prior to a mating experiment slugs were usually isolated for several days to increase their readiness to mate.

Slugs to be mated were placed in transparent plastic containers $113 \times 113 \times 36 \mathrm{~mm}$. The bottom was partly covered with damp tissue paper and a fallen beech leaf. Usually two slugs were put together, but in a few cases with the Sicilian material we put in three individuals and then removed the third if two started to court. Slugs were observed in subdued or red light until they started to court. We then took off the lid (inverting it if they were mating on the lid itself) so that couples could be video-recorded (requiring somewhat brighter white lighting).

The matings of the Maltese and a few Sicilian slugs were recorded with an analogue Sony CCD-VX1E/PAL camcorder. Recordings were limited to one couple at a time, but usually four couples were set up simultaneously. If couples courted simultaneously, the most progressed couple was video-recorded, while we attempted to observe the others directly. Data are also sometimes missing because many couples were partly recorded using interval mode $(2 \mathrm{~s}$ every $30 \mathrm{~s}$ ). For the other matings we used a digital video recording card allowing four-channel recording from a diversity of cameras (for technical details, see HUTCHINSON \& REISE 2009).

\section{DNA SEQUENCING}

We extracted DNA from foot muscle, albumen gland or gonadal tissue of slugs preserved in $70 \%$ alcohol following the method described by WINNEPENNINCKX et al. (1993). The mtDNA COI region was amplified using primers LCO 1490 (5'-GGTCAACAAAT CATAAAGATATTGG-3') and HCO 2198 (5'-TAAACTTCAGGGTGACCAAAAAATCA-3') (FOLMER et al. 1994). Each PCR contained $2.5 \mu \mathrm{l}$ of $10 \times$ PCR buffer (200 mM of Tris-HCl, pH 8.55; 160 $\mathrm{mM}$ of $\left(\mathrm{NH}_{4}\right)_{2} \mathrm{SO}_{4}, 20 \mathrm{mM}$ of $\mathrm{MgCl}_{2} ; 0.1 \%$ Tween $), 1$ unit peqGOLD Taq-DNA-Polymerase, $4 \mathrm{nmol}$ of each dNTP (peqlab, Erlangen, Germany), $5 \mathrm{nmol}$ of primer forward and reverse respectively and $2 \mu \mathrm{l}$ template DNA. Sterile water was added to a total volume of $25 \mu \mathrm{l}$. The PCR thermal regime consisted of one cycle of 5 min at $95^{\circ} \mathrm{C} ; 35$ cycles of $45 \mathrm{~s}$ at $95^{\circ} \mathrm{C}, 45 \mathrm{~s}$ at $40^{\circ} \mathrm{C}$ and $1.5 \mathrm{~min}$ at $72^{\circ} \mathrm{C}$ and a final cycle of 5 min at 
$72^{\circ} \mathrm{C}$. The resulting c. $650 \mathrm{bp}$ fragments were purified using the QiaQuick Gel Extraction Kit (Qiagen, Hilden, Germany) according to the manufacturer's instructions and sent to sequencing services (StarSeq, JenaGen) or Laborzentrum BIK-F for direct sequencing, most often in both directions. Sequences were aligned by eye. Most nucleotide substitutions were silent, so in rare cases where a single individual showed non-silent substitutions we manually rechecked the abi files of that region.

Of the 656 base pairs between the primers, a mean of $96 \%$ were identified (minimum 554; 569 for our own sequences). Prior to further analysis we removed duplicate sequences.

\section{RESULTS}

\section{MORPHOLOGY}

Externally, D. panormitanum, D. golcheri and the tramp species are not reliably distinguishable. The specimens of the tramp species included in this study were light to dark brown. D. panormitanum and $D$. golcheri ranged from light grey, pinkish cream and creamy brown to dark brown, grey or even, in some $D$. panormitanum, almost black. The three species usually have a more or less dense dark spotting on the back and sides and particularly on the mantle. However, unspotted specimens of the tramp species occur. The pigment dots are usually more apparent in alcoholpreserved specimens. The body mucus is watery and transparent.

GIUSTI et al. (1995) claimed that dense dotting forming a dark line over the pneumostome was a reliable character to distinguish $D$. golcheri from $D$. panormitanum on Malta. However, we found that it can be present or absent in both species on Malta, confirming the conclusion of WIKTOR (2000) that it is not a reliable character.

The rectal caecum in the three species is a small extension, but it can sometimes be entirely missing, at least in the tramp species. Genital anatomy provides the only reliable morphological characters for identification. The penis (Figs 2, 3) consists of a proximal part, onto which two side pockets (the penial lobe and penial caecum) insert, and a distal part containing the sarcobelum. However, in some $D$. panormitanum the base of the proximal part was so small and hard to distinguish from the distal part that the penis appeared short and almost spherical, with the side pockets appearing as though attached to the main (distal) bag (Fig. 2g-m).

The length and the shape of the penial pockets vary among and within species. In the tramp species,
Because there is no reliable phylogeny for Deroceras (WIKTOR 2000), as the outgroup we used Limax maximus L. (from Baruth, Germany).

The program Tree-Puzzle v.5.2 (SCHMIDT et al. 2002) constructed a maximum-likelihood tree. Based on comparisons using jModelTest (GUINDON \& GASCUEL 2003, POSADA 2008) we specified the HKY model of base substitution with a mixed model of rate heterogeneity (six gamma-distributed rates and a fraction of invariable sites). The program MrBayes v. 3.1.2 (HUELSENBECK \& RONQUIST 2001, RONQUIST \& HUELSENBECK 2003) constructed a tree using Bayesian inference. Default parameters were used except that we specified the same HKY model as above. We report a consensus tree from the last $10^{6}$ generations of $5 \times 10^{6}$ generations.

the penial lobe and caecum are both well developed, of comparable width, and bluntly rounded at the end. The caecum is usually slightly bent and longer than the lobe; if not short and stout, the lobe is usually more bent than the caecum. In D. panormitanum, these penial pockets differ strikingly from each other. The caecum consists of a bulky base on which inserts a long, thin and somewhat bent pocket that tapers towards the tip; this is the easiest character to distinguish $D$. panormitanum from the tramp species. On one side (roughly facing the penis bag), the caecum usually appears slightly lobed (Fig. 2c, 1, m) reminiscent of the (thinner) fingers of the penial gland and in contrast with the unlobed appearance in the tramp species. The penial lobe is considerably thicker than the caecum, although its size and shape vary considerably. It can be a long pocket, as in the tramp species (Fig. 2i, j), but it may be reduced to various extents (Fig. 2a, c, d, k-m). In some Maltese material it is reduced to not much more than the swelling in D. golcheri (see below), but nevertheless such individuals mate successfully with individuals with a long penial lobe, and even in a specimen with the lobe apparently missing (Fig. 2k-m) the lobe was present and well visible in the everted genitalia. Even when the lobe is present it can be difficult to recognise: in some Sicilian specimens the penial lobe is not very apparent because it is tightly fixed to the main penis bag by branches of the retractor (Fig. $2 g, h$ ).

The penis of $D$. golcheri never has the clear side pockets of $D$. panormitanum or the tramp species. There are usually one or two terminal, but slightly lateral, swellings or extensions (called "tubercles" by AltenA 1962), developed to varying extents; the more prominent one is at the side opposite to the insertion of the penial gland (Fig. 2O-r). This positioning and the insertions of vas deferens, penial gland 

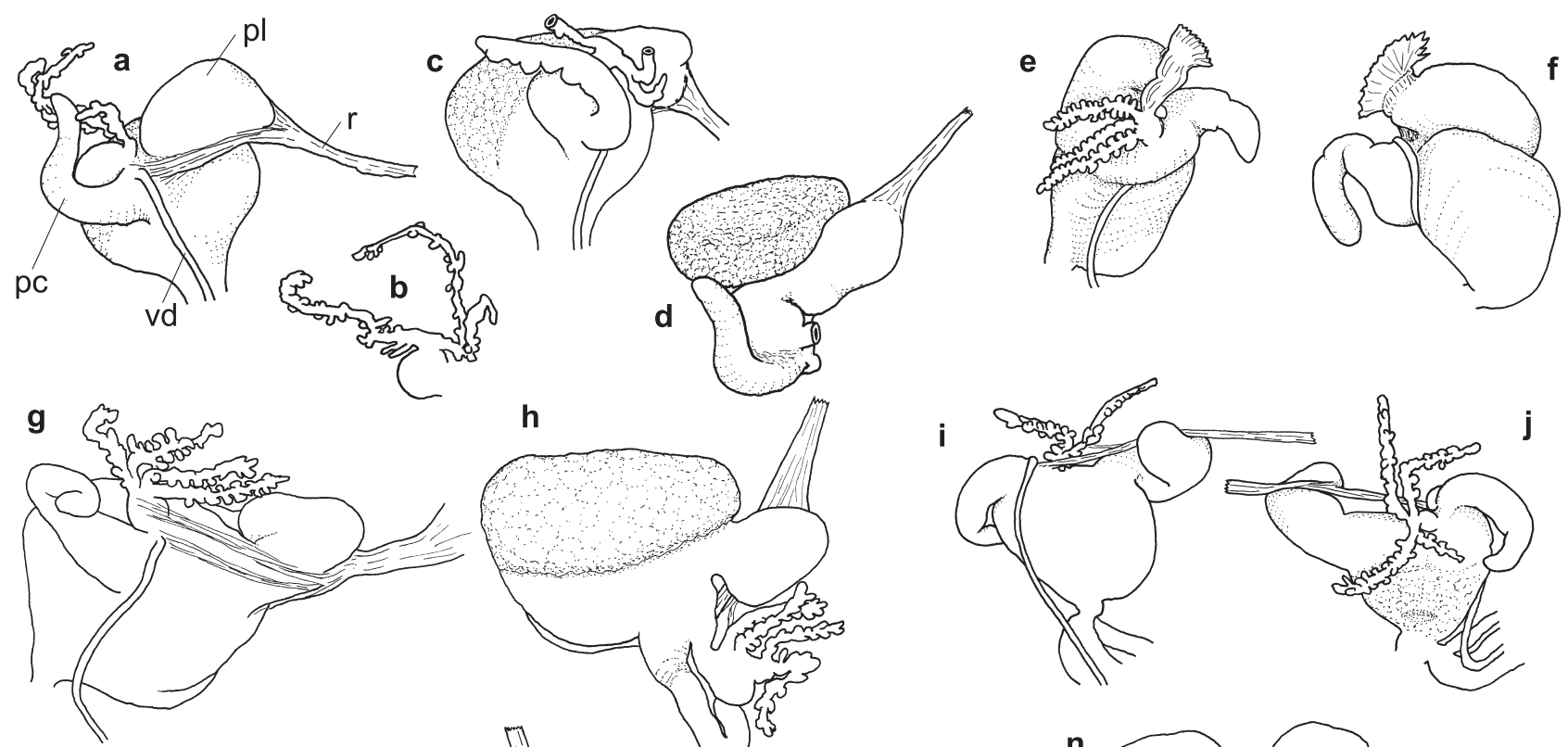

$\mathbf{h}$

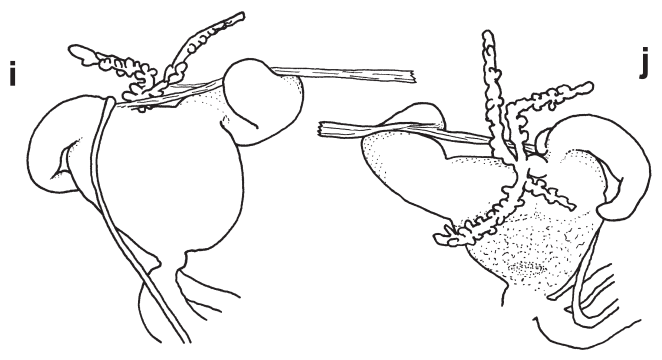

$\mathbf{k}$
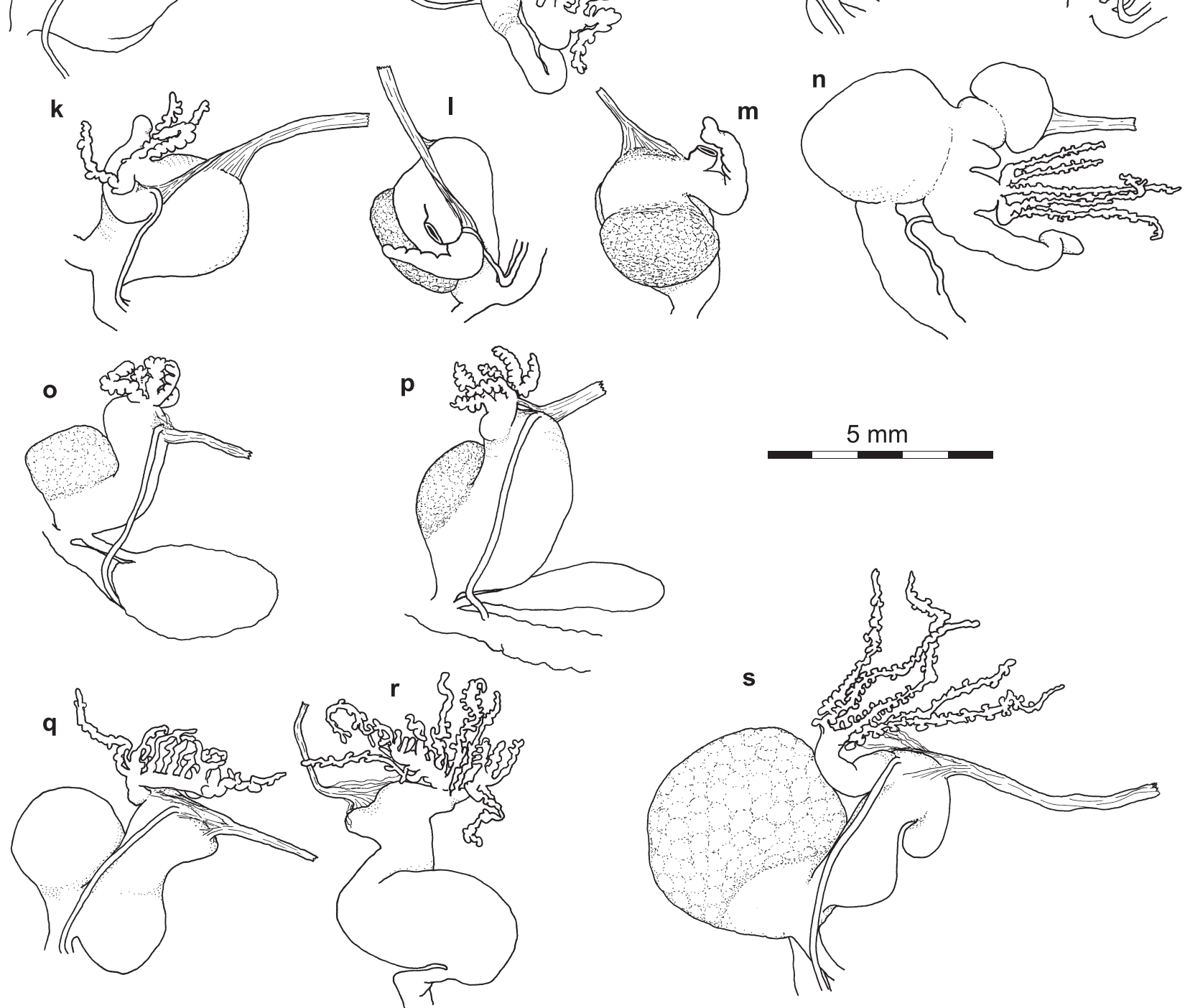

Fig. 2. Penis of D. panormitanum (a-n), D. golcheri (o-r) and species X (s) from Sicily and Malta: a-d - typical specimen, from site S1 (pc - penial caecum, pl - penial lobe), in a the penial gland band is held back to show insertion of vas deferens (vd) and retractor (r); e, f - typical specimen, from M5; g, h - specimen from S5, apparently lacking a clear proximal part of penis (except caecum and lobe), but this part becomes clearly visible when pinned out (h); i, j specimen with unusually long lobe, from M4; $-\mathrm{m}$ - specimen with lobe externally absent but present when copulated, from M7; $\mathrm{n}$ - also from M7, with untypical shape of penial lobe; $\mathrm{o}$ - from M8; $\mathrm{p}$ - from M9; q, r - specimen with very untypical penial gland, from M8; s - from S6 
and retractor suggest homology with the penial lobe (cf. GIUSTI et al. 1995, who refer to an "indistinct penial caecum").

In the tramp species and D. panormitanum, the appending penial gland and the vas deferens open into the proximal penis between the lobe and the caecum; they insert almost midway between these side pockets in the tramp species while in $D$. panormitanum they clearly open into the bulky base of the caecum (Fig. 2a, $\mathrm{d}, \mathrm{g}-\mathrm{h}, \mathrm{m}, \mathrm{n})$. In $D$. golcheri, the gland inserts somewhat laterally on the proximal end of the penis, and the vas deferens inserts a short distance away (Fig. 2o-q).

In the tramp species, the penial gland consists of 3-7 fingers on a common base; they are usually, but not always, unbranched and unlobed. If they are lobed (Fig. 3a-g) the lobes are weak and never as developed as in the other two species (Fig. 2a-r). In $D$. panormitanum, the 3-6 fingers of the gland are also usually unbranched but always strongly lobed. The same applies in $D$. golcheri but, in contrast to the other two species, its usually 3-5 gland fingers are stronger, a little shorter, and often insert directly on the penis in something like a circle (WIKTOR 2000), the ends bent towards each other like the petals of a closed flower (Fig. 2o). However, in some D. golcheri these fingers do insert on a common stem (Fig. 2p-r, figures in GIUSTI et al., 1995). The specimen in Fig. 2q, r has unusually many, long, and strongly branched gland fingers; an offspring also has rather long gland fingers but only five and unbranched.
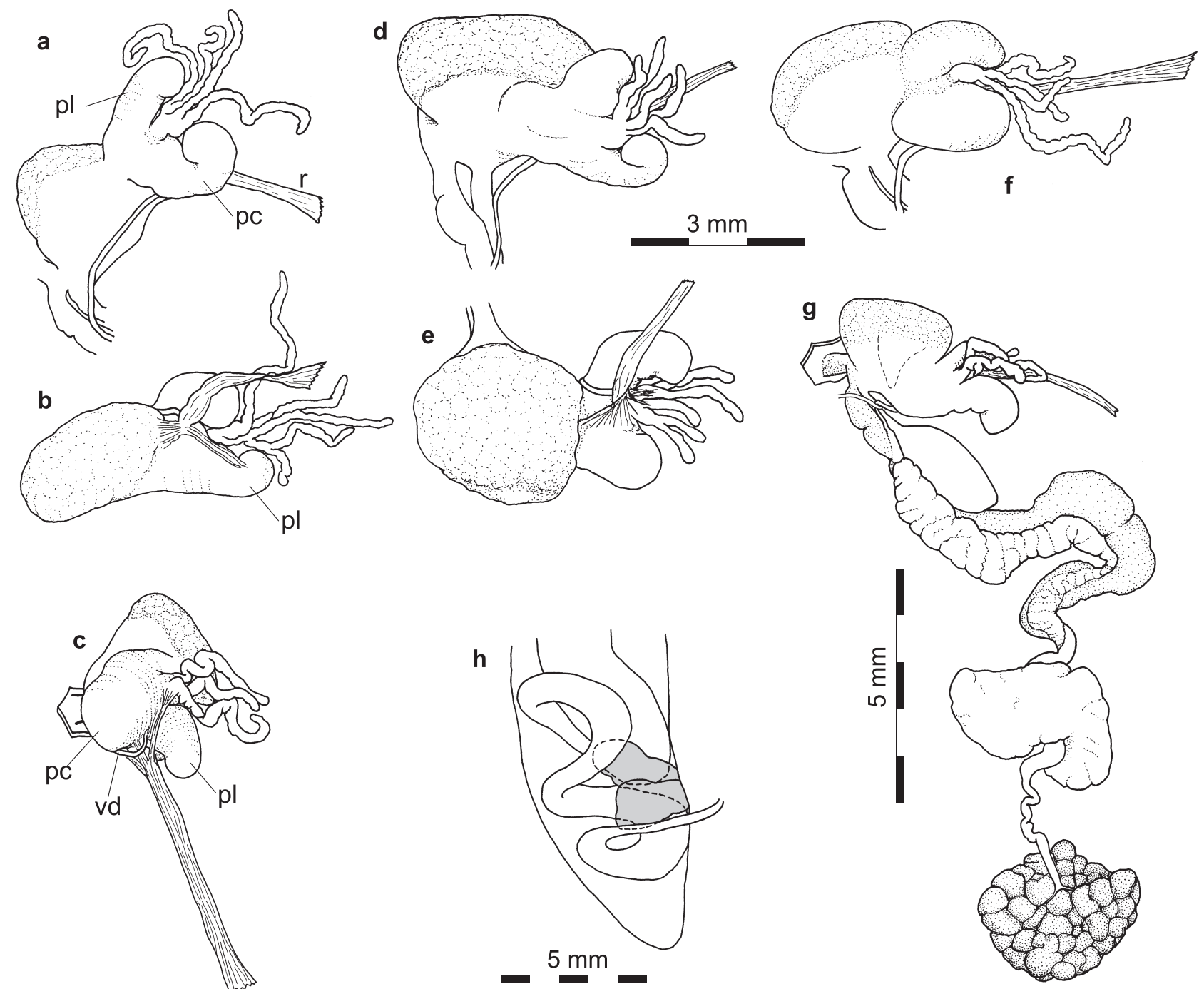

Fig. 3. Anatomy of Deroceras invadens sp. n. (the tramp species): a, b-holotype: typical penis with long caecum (pc) and lobe $(\mathrm{pl})$, accordingly long branch of the retractor $(\mathrm{r})$ attaches to the lobe (b), gland fingers long; $\mathrm{c}$ - paratype (SMNG no. p16552): view from posterior side onto proximal part of penis showing insertions of retractor, vas deferens (vd) and appending penial gland (the latter has been forced back); $\mathrm{d}, \mathrm{e}-\mathrm{two}$ views of a penis with shorter penial lobe and the retractor only leading to its base, shorter fingers of appending penial gland; f - paratype (SMNG no. p16553) with slightly untypically bulky penial caecum; g - entire genital tract of a paratype (SMNG no. p16554), dashed line indicates position of sarcobelum within the distal part of penis; $\mathrm{h}$ - digestive tract and position of gonad (shaded); dashed lines indicate hidden parts. Scale is the same for a-f. All specimens from type locality, collected 28.7.2005 (d, e) or otherwise 23.1.2006 
The penis retractor is usually well developed. In the tramp species, it inserts between the lobe and the caecum, and some branches lead to the base of the penial gland, to the margin of the distal penis, to the penial lobe, and to the base of the caecum (Fig. 3b, c, e). In D. panormitanum, the main part of the retractor inserts on the side of the penial lobe. From there, some branches continue to the base of the caecum and some other fine branches to the base of the penial gland and to the lower parts of the gland fingers (Fig. 2a, f, g, j, k). In D. golcheri, the retractor inserts at the lateral extension (or where the extension would be), just beside the vas deferens; one branch leads to the penial gland (Fig. 2o-q).

Now we consider characters exposed by cutting the penis open (Fig. 4). In all three species, the sarcobelum is a slightly flattened cone that is shorter than in D. reticulatum. The wall of the penis bag around the sarcobelum base is very glandular and thick.

Another glandular field lies on the inner wall of the distal penis at its margin with the proximal penis. In the tramp species and D. panormitanum this field is small and fairly distinct, but may extend, getting weaker, towards the base of the sarcobelum (Fig. 4a, b, e). In $D$. golcheri, it is much thicker and larger, stretching far into the proximal penis and causing the base of the proximal penis to swell out (Fig. 4c). It is probably this glandular field where the partners nibble just before full penis eversion starts and later the ejaculate is deposited onto it (see next section on mating behaviour).

At the transition between the distal and proximal parts of the penis, the penis narrows abruptly, which is where a small flap inserts in D. panormitanum (Fig. 4a, b). This flap is usually rounded and thick, but in a couple killed immediately after copulation the flaps are very thin, resembling the thorn of a rose. During copulation when the penis is fully everted, the flap flanks the ejaculate received from the partner (Fig. $5 c)$. This flap was present in all specimens of $D$. panormitanum checked and never in the other species.

We also have two single specimens from two localities on Sicily which we call species $\mathrm{X}$ in this paper. The proximal part of the penis is much narrower than in the other three species. Laterally at the proximal end sits a side pocket which in one specimen looks like an extremely strong and long base of the appending penial gland (Fig. 2s) but in the other specimen like a bent extension of the main proximal penis bag. On the end of this side pocket inserts the penial

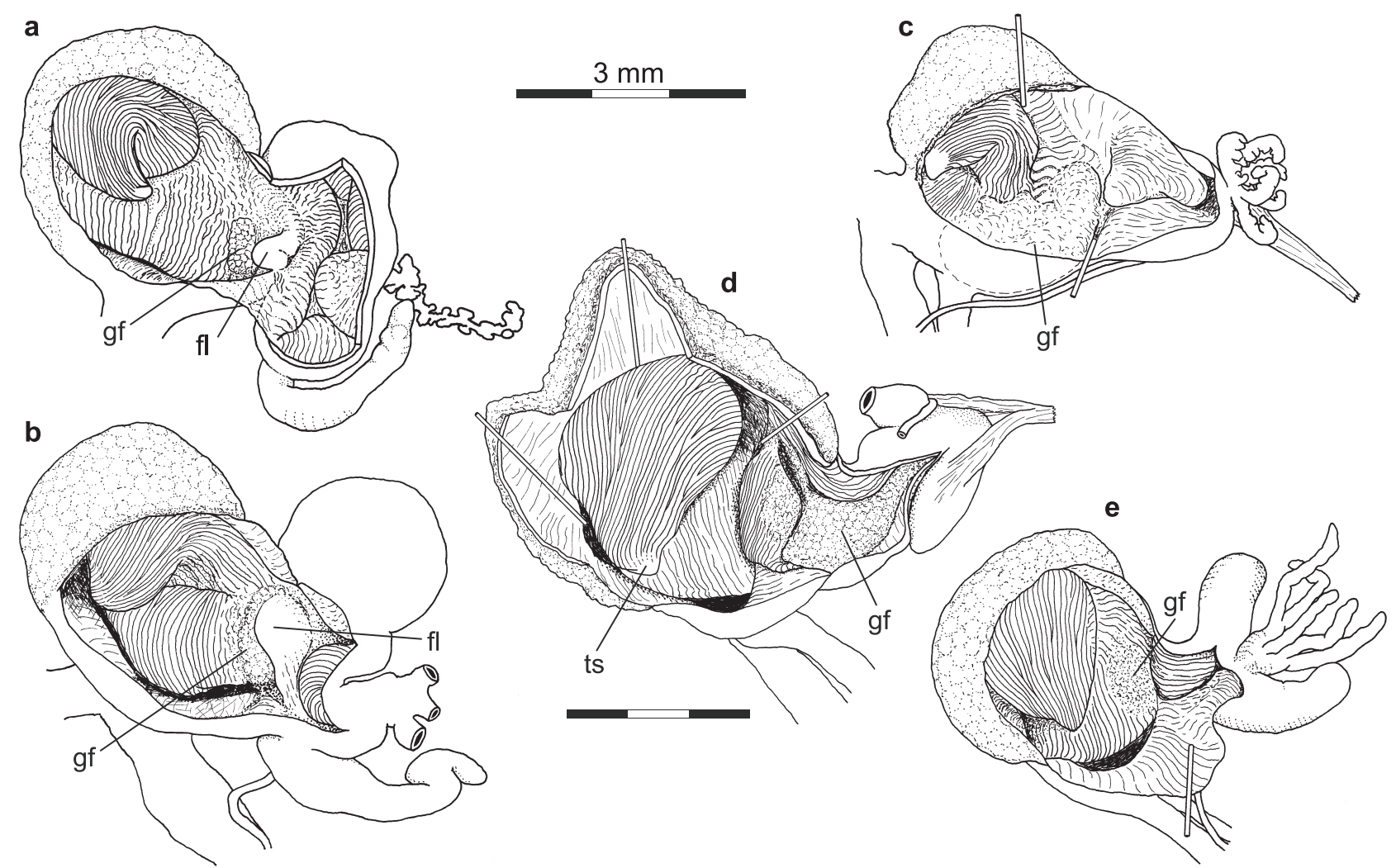

Fig. 4. The interior of the penis in D. panormitanum (a, b), D. golcheri (c), species X (d), and the tramp species (e). All species show a sarcobelum (ts - tip of sarcobelum) and a glandular field (gf), which varies in position and size between species (dotted line in c indicates hidden outline). Only D. panormitanum exhibits the distinctive flap (fl). Note that (d) is to a slightly different scale as the specimen had grown large in the laboratory. Localities (for site numbers see Table 1): a - F1 offspring of a specimen from S1, b - M7, c - M8, d - S6, e - E1, coll. 28.7.2005 
gland, consisting of 5 to 6 long, unbranched, strongly lobed fingers on a common base. In one specimen, opposite to this side pocket is another side pocket (Fig. 2s), but in the other specimen it is only a slight extension. The retractor inserts at the posterior end of the proximal penis, near where the vas deferens enters the penis. The sarcobelum is as in the other three species. The penis structure is reminiscent of $D$. golcheri in having a similarly extensive glandular field and in lacking the penial caecum and lobe and the flap found in D. panormitanum. The specimens nevertheless seem morphologically distinct from $D$. golcheri as they have a considerably narrower proximal penis that is extended proximally to some kind of side pocket, and the penial gland is more prominent.

\section{MATING BEHAVIOUR}

Our observations revealed three discrete types of mating behaviour corresponding with the morphological groups, $D$. panormitanum (from Malta and Sicily), D. golcheri, and the tramp species. These mating behaviours are described below and videos can be found by following the link at http://sites.google. com/site/panormitanum. Mating of species X was not observed, but it was involved in some interspecific matings (see below).

\section{Tramp species}

In the course of various experiments we have observed hundreds of matings of this species originating from site E1. However, most quantitative results presented are from just one such study (Table 1), yielding data on 65 successful matings, in which the meth-
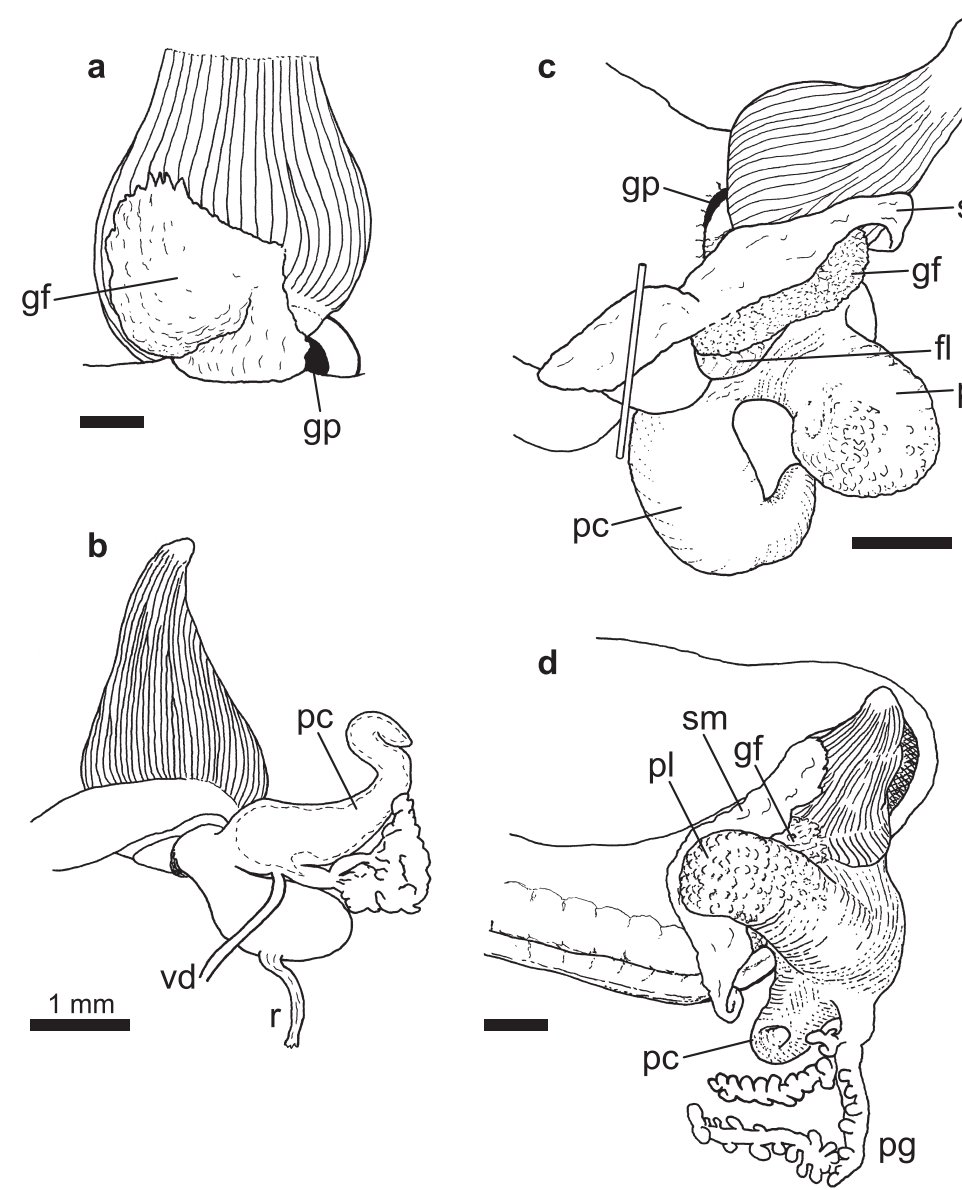

e
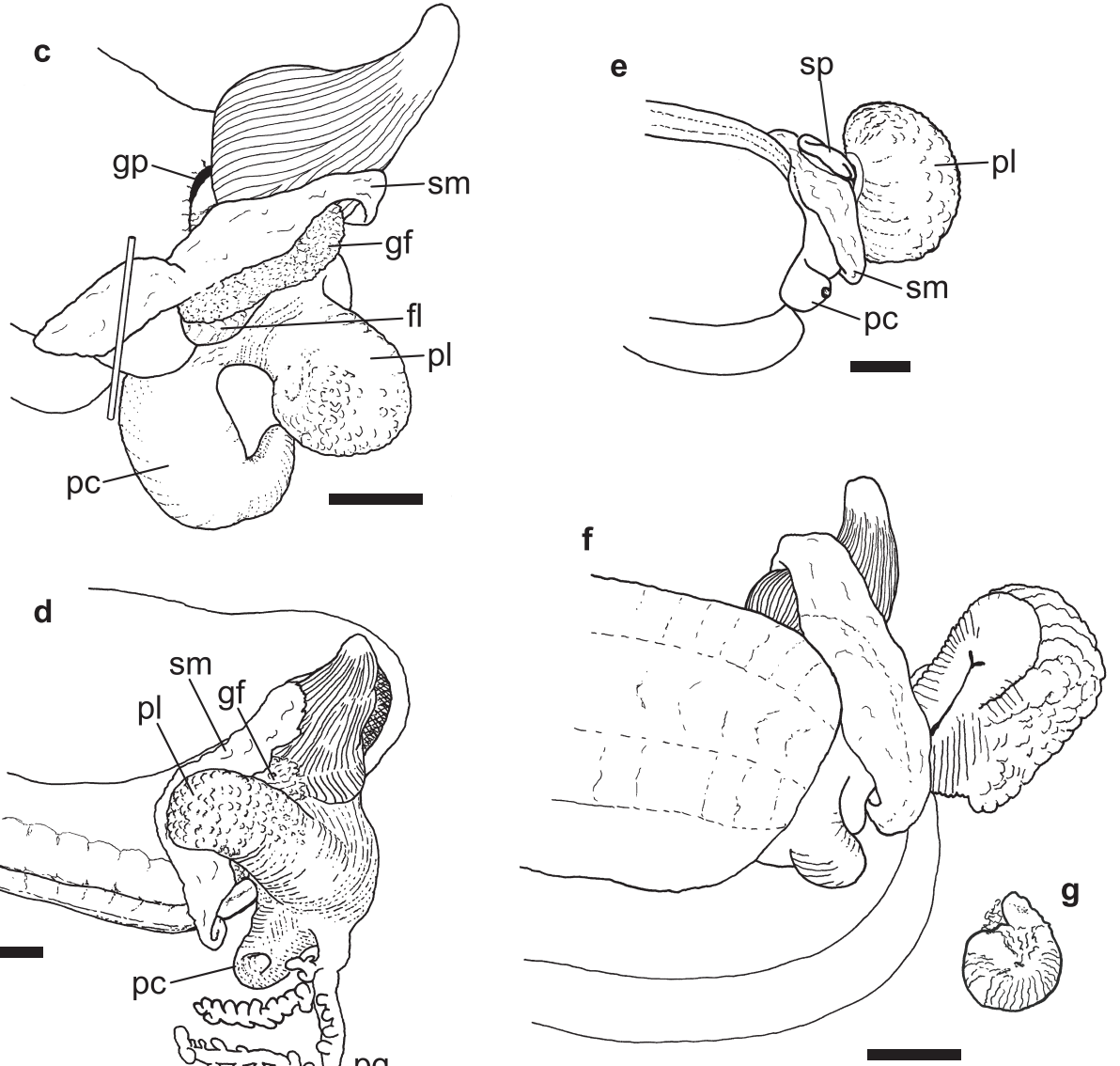

Fig. 5. The anatomy of mating in D. panormitanum: a - lateral view of protruded sarcobelum, showing the glandular field (gf) and the genital pore (gp); b - view from inside the slug looking out through right side towards the protruded sarcobelum, the dashed line inside the penial caecum (pc) marks where sperm has accumulated immediately before copulation; c, d - lateral views of each partner of a couple killed during copulation, showing the still partially everted penial caecum, the penial lobe ( $\mathrm{pl}$ ) and the sperm mass $(\mathrm{sm})$ overlying the glandular field. Both penial glands (pg) were already everted but that in c lies hidden. In $\mathrm{c}$ the sperm mass has been pushed aside a little to reveal its position relative to the flap (fl); e, f - views of another slug killed in copulation. In e original position with a secretory plate (sp) sandwiched between the underside of the penial lobe and the sperm mass. In $\mathrm{f}$ the penial lobe has been lifted and the secretory plate removed (shown to same scale in $\mathrm{g}$ ). Scale bars are all $1 \mathrm{~mm}$. Localities: a, b - F1 offspring of slug from S3; c, d - F2 offspring of slugs from S1; e-g - F1 offspring of slugs from S2 
odology closely matched that for our observations of Sicilian D. panormitanum. Others' descriptions of this species' mating are largely compatible (see REISE 2007 for a review); their reliance on direct observation rather than close-up recordings probably explains slight discrepancies in reported copulation behaviour.

Precourtship involves "trail following" in which one slug follows closely behind the partner, its tentacles straddling the leader's tail. Unlike in normal locomotion, the tails may be flattened and expanded vertically. The follower can pursue a leader that has got some distance ahead, presumably by utilising the slime trail. Occasionally one slug may bite the other and the victim will lash its tail and accelerate away. A bout of precourtship behaviour lasts typically 11-34 min (interquartile range) before both sarcobela have protruded, but sometimes multiple bouts are necessary, separated by intervals when contact has been lost or the partners appear disinterested. Often it is when the leader turns back that its sarcobelum protrudes, and the follower protrudes its sarcobelum when the animals have formed a rotating circle in which each follows the other. But there is much variation in when during this sequence each sarcobelum protrudes and in the interval between the two protrusions $(>5 \mathrm{~min}$ is not unusual).

We count courtship as starting once both sarcobela have protruded (REISE 2007). For a short time each partner may remain peacefully attending to the other's tail. But a violent phase follows, involving rapid lunges towards the partner with the mouth stretched forward in an attempt to bite (Fig. 6a-d). Lashing the tail side to side is a common response (Fig. 6b), as is a lunge back (Fig. 6d). The animals may assume more of a head-to-head configuration as they trade blows directed toward the head and mantle. But the commoner configuration, particularly later, is head to tail in a circle. The circle rotates, but rather jerkily, as if the rotation is a side-effect of the lunging. Between lunges the sarcobelum is held nearly vertically with the tip bent backwards, but during a lunge it is brought horizontal and may contact the partner.

After some minutes the frequency of lunging declines, and it is replaced by less aggressive-looking behaviour in which the sarcobelum lashes forward over the tail of the partner, stroking the partner's back or flank limply like a paint brush before flicking back to the vertical position (Fig. 6e). Sometimes it is clear that these strokes transfer drops of secretion from the tip of the sarcobelum onto the partner. No obvious response by the partner is apparent and nor are the partners synchronised in these strokes, except that after the occasional aggressive lunges that still occur both partners keep the sarcobelum vertical for a time. The tip of the tail remains expanded vertically (Fig. 6e). Rotation of the circle slows right down.
Late in courtship the heads are redirected from the tail towards the flank of the partner, so that they form a loose yin-yang configuration rather than a circle (Fig. 6f). The sarcobela may then be applied to the flanks, but mostly they remain vertical and instead there is occasional mouth contact with the partner's flank. Mouth contact with the base of the partner's sarcobelum (Fig. 6g, h) leads to copulation. The duration of courtship correlates negatively with temperature (HuTCHINSON, JÄSCHKE, SCHULZE \& REISE, unpublished); at $15^{\circ} \mathrm{C}$ the median duration is $96 \mathrm{~min}$ (quartiles: $88,106 \mathrm{~min}$ ), whereas at $20^{\circ} \mathrm{C}$ a duration of $70 \mathrm{~min}$ is typical.

As the slugs nibble on the sarcobelum base of the partner, the heads twist round to the right (Fig. 6h). The twisting brings the sarcobelum bases into contact with one another, which seems to trigger eversion of the rest of the penis from the anterior side of the sarcobelum base. The penial caecum everts to form a long finger that shoots forward and hooks round the back of the partner's sarcobelum, depositing sperm on the blade of the sarcobelum (Fig. 6j); this takes 3-5 s. The penial caecum soon contracts, although it is not fully retracted, but the bag-like base of the penis remains placed against that of the partner (Fig. 6k, 1). For a period of typically a minute, but sometimes many minutes, all one can see are rhythmic pumping movements of this part of the penis.

The penes may or may not have separated from one another when the penial lobe everts to form another finger-like projection: this is much shorter than the penial caecum at its full extent (Fig. 6m). It everts to the right and forward, reminiscent of a boxer's right hook to the belly of the opponent. Partners rarely evert this organ simultaneously. Occasionally the lobe hooks round the contracted but still partially everted penial caecum (Fig. 6i), but too rarely for that to be its function; more often it weakly bumps into the partner's penis or misses altogether.

The penial lobe contracts as soon as it has fully extended and then immediately the appending penial gland everts from a spot on the left (anterior) of the bag-like base of the penis (Fig. 6n). The fingers of this gland are particularly long in this species and they spread like a net over the whole flank of the partner, sometimes reaching over to its left side and down to its tail (Fig. 6o). One partner usually everts the gland later than the other (median $=61 \mathrm{~s}$ later), so sometimes the first partner has already crawled out of range by the time the second everts its penial gland. BENKE et al. (2010) demonstrated that the gland deposits a secretion onto the partner. Retraction of the gland is followed directly by retraction of the sarcobelum and the animals then crawl apart. The median duration of copulation (i.e. until the penes lose contact with the partner) was $267 \mathrm{~s}$ (quartiles: 221, $342 \mathrm{~s}$ ). A few minutes after the separation the slugs often bend tightly back to eat mucus off their body, possibly 

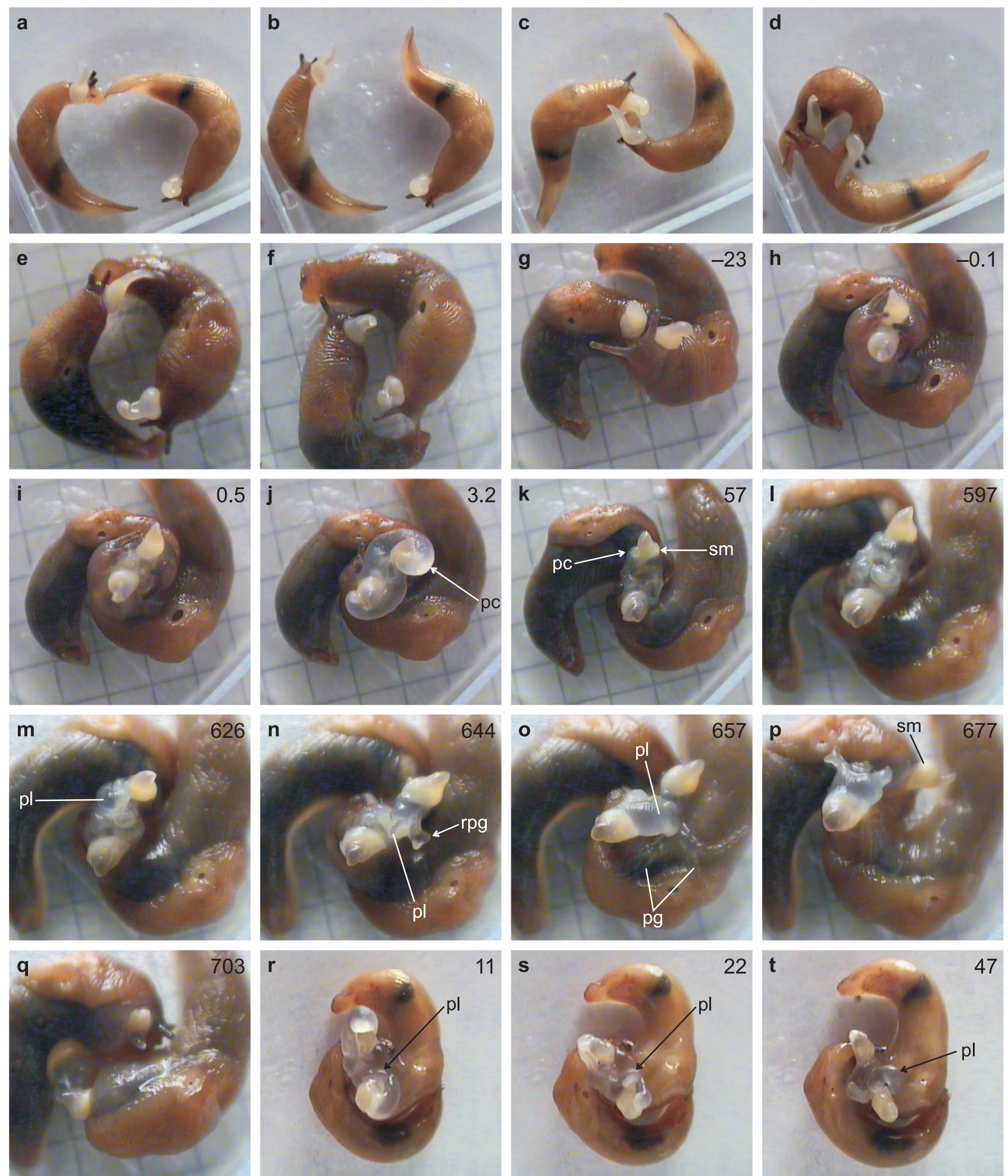

Fig. 6. Video-stills of mating in the tramp species: a-d and r-t are from a mating from slugs collected in Cala di Luna, Sardinia, the rest from a mating of slugs bred from collections from Nork Park, Banstead, England. Figures in the top right of each figure give times in seconds relative to the start of copulation; $\mathrm{a}-\mathrm{d}$ - the aggressive phase early in courtship; a - one slug bites the partner's tail; $b-0.7 \mathrm{~s}$ later the victim has thrashed its tail away; $\mathrm{c}-\mathrm{a}$ bite directed to the partner's sarcobelum; $\mathrm{d}-\mathrm{one}$ slug is biting the tail of the partner, which in retaliation bends sharply round to bite the attacker's head; e - circular head-to-tail configuration typical of the middle of courtship, one partner strokes the partner's tail with its sarcobelum whilst the partner's sarcobelum is curved back and held upright (Note the expanded flag-like tail, particularly of the right-hand slug.); $\mathrm{f}$ - late courtship with both sarcobela held upright and attention shifted from tail to flank; $\mathrm{g}$ - beginning to nibble the base of the partner's sarcobelum; $\mathrm{h}$ - immediately prior to copulation, with the bases of the sarcobela brought together; ithe start of penis eversion; $\mathrm{j}$ - full eversion of one penial caecum (pc) around the partner's sarcobelum, with the other 
to remove the secretion of the penial gland (BENKE et al. 2010). They may also return to the site of mating and eat mucus off the ground.

The three copulations from the Sardinian population differed slightly from the above account based on the British material. In the Sardinian slugs the penial lobe everted while the penial caecum was retracting and tended to be directed more backwards towards the animal's own sarcobelum (Fig. 6r-t). Note, however, that we have observed single instances of both these behaviours in the English pairs. The penes then separated without the massaging phase, and non-synchronous eversions of the penial glands followed after an interval of about a minute. Total duration of copulation was similar to the English material.

We also studied a single specimen from Sicily (Site S9) that morphologically agreed with the tramp species. In a copulation with a conspecific from England (site E1) both partners everted simultaneously. The penial caecum of the Sicilian looked typical of the tramp species in shape and mode of eversion, but it missed the sarcobelum of the partner (hooking round too short), so sperm transfer was unilateral.

\section{Deroceras panormitanum}

Our mating data on Maltese $D$. panormitanum are based on 44 couples (involving 54 individuals from altogether seven sites) that showed some mating behaviour, 42 of which continued to courtship, and 34 copulated. Our mating data on Sicilian D. panormitanum are based on 30 couples (involving 36 individuals from altogether 6 sites) that courted, of which 24 copulated reciprocally.

Precourtship is similar in all three species considered here; because the precise pattern varies so much between matings of the same species it would be hard to establish any interspecific differences. The flattened tail in D. panormitanum is even more prominent than in the tramp species, forming almost a circular silhouette (Fig. 7a).

As in the tramp species, the second sarcobelum to protrude often does so soon after a circle configuration has formed, probably because the follower requires the stimulation of being trail-followed. Also as in the tramp species, the start of courtship is very violent, with the animals trying to bite one another, particularly along the right flank. Biting near the tail re- sults in tail lashing. But unlike in the tramp species, the circle configuration does not persist for long (it occurred in less than half the Maltese couples and lasted on average only $5 \mathrm{~min}$ ). This fighting phase is usually followed by a head-to-head stand-off in which the animals are out of contact, but wave their heads as if trying to sense the other and then periodically lunge with bared jaws towards the head of the partner. It is reminiscent of a fencing match. The sarcobelum blade is mostly curled back pointing almost vertically (Fig. 7a), but when the animals lunge to bite the sarcobelum swipes forward also and may contact the partner. This aggressive phase typically lasts a third of the courtship.

A new behaviour pattern then occurs: the partners advance towards each other, first making contact sarcobelum to sarcobelum and then each strokes its sarcobelum along the flank of the partner as their bodies rub past each other (Fig. 7c). This close flank-to-flank rubbing as the partners lie antiparallel is characteristic of the species. Once the sarcobelum reaches the partner's tail, trying to maintain contact with the partner ensures that each slug doubles sharply back and takes up the position previously occupied by its partner. They then become stationary again and may again "fence". Such alternation of a face-to-face stationary phase and half a turn slowly sliding past each other continues until the partners try to copulate. A typical duration for half a turn is $2.5 \mathrm{~min}$, increasing later, and each pair makes an average of 13 half turns (but it may be half or double this). Initially, the peaceful stroking along the flank may be interrupted by an occasional bite, but biting diminishes in frequency, and fencing in the stationary phase is replaced by the sarcobela fondling each other (Fig. 7b).

The copulation phase develops from such a stationary face-to-face position, but at this point the partners nibble on each other's mouths (Fig. 7d) and push against each other so that the heads rear up dramatically into the air (Fig. 7f). Both these aspects are in contrast to the tramp species. Typically each head twists slightly to the right and the consequent helical coil perhaps stabilises the configuration; nevertheless sometimes the tower falls over so that one partner lies over the other, which may, but need not, delay further progress. Getting into a position where both partners

caecum still everting at the very tip; $\mathrm{k}$ - the caeca have mostly contracted, leaving a sperm mass ( $\mathrm{sm}$ ) attached to the sarcobelum; 1 - little change in configuration after a further 9 min during which the penes massage each other; $\mathrm{m}$ penial lobe $(\mathrm{pl})$ of the left-hand slug fully everted, happening to grip the partner's contracted penial caecum; $\mathrm{n}-\mathrm{the}$ penial lobe has now contracted and the root of the penial gland (rpg) has everted immediately prior to the gland fingers everting; o - the gland fingers are now everted over the partner (pg labels two of the five fingers) whilst the penial lobe of the right-hand slug now everts; $\mathrm{p}$ - the right hand slug is now in the same state as the partner was in $n$, all but the sarcobelum of the partner is now retracted, revealing the full extent of the sperm mass stuck to its posterior side; $q$ - all but the sarcobela of both partners retracted: they will retract fully in another $52 \mathrm{~s}$ and the tentacles will re-emerge after a further $20 \mathrm{~s} ; \mathrm{r}$ - full eversion of the penial caecae in a Sardinian pair, the penial lobe of the slug lower in the picture is already visible; $\mathrm{s}$ - as its penial caecum retracts the penial lobe expands; $\mathrm{t}$ - full eversion of the penial lobe 
are willing to proceed often requires several attempts, which may significantly prolong courtship. If one partner is unsatisfied it crawls a $360^{\circ}$ loop so as to reencounter the partner head-on afresh; such behaviour occurs also in the tramp species. As the twisting of the heads becomes more pronounced the nibbling is redirected onto the base of the partner's sarcobelum (Fig. 7e); furthermore the two bases contact one another, which appears to trigger full penis eversion. Duration of courtship tends to be longer in our Sicilian pairs (median 102 min; quartiles: 73, 187 $\min ; N=20$ ) than in our Maltese pairs (median 70 min; quartiles: 57,$96 ; N=31$ ), which can be only partly explained by the cooler temperatures at which half of the Sicilian pairs were studied.

Penis eversion is much faster than in the tramp species (maximum eversion of the penial caecum is within $1 \mathrm{~s}$ ), but is similar in that the first step is the long penial caecum hooking round the back of the partner's sarcobelum. The caecum is more tentacle-like in $D$. panormitanum and only a sliver of ejaculate can be seen to be deposited by its pointed tip onto the base of the blade of the sarcobelum (Fig. 7h; most sperm is deposited elsewhere, see below).

Before the penial caecum has extended fully, the penial lobe starts to evert to form another finger,
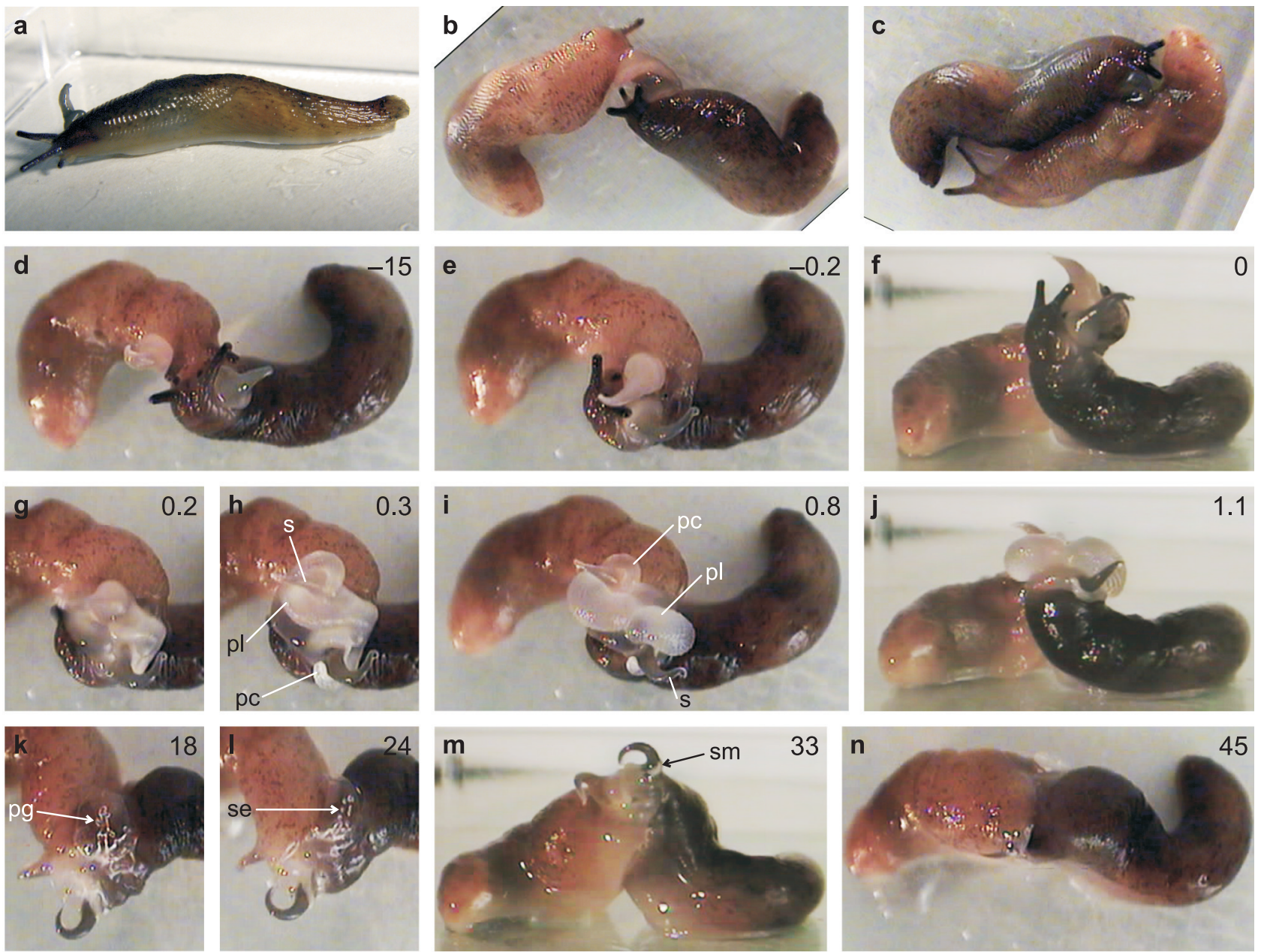

Fig. 7. Mating in D. panormitanum from S5, Sicily: b-n are video-stills from one mating. Figures in the top right of each figure give times in seconds relative to the start of copulation; $\mathrm{a}-\mathrm{a}$ specimen in early courtship temporarily out of contact with the partner: note the upward curve to the sarcobelum and the expanded tail; b - courtship: mutual fondling between sarcobela as the slugs re-contact after turning round; c - courtship: rubbing alongside each other; $d$ mouth-to-mouth nibbling before copulation; e, f - spiralling upwards immediately prior to copulation, with the sarcobelum bases about to contact each other; $g$ - mid-eversion: the penial caecum of the pale slug has just reached behind the partner's sarcobelum, and its penial lobe begins to expand; $\mathrm{h}$ - eversion continues: the marked penial caecum (pc), the penial lobe (pl) and the sarcobelum (s) all belong to the pale slug (Both penial caeca have expanded fully depositing sperm on the sarcobela. The penial lobes are partially expanded, less so that of the dark slug.); $i, j-$ the penial lobes fully expanded (Labels in i are as in $\mathrm{h}$, but now referring to the other, dark slug.); $\mathrm{k}$ - eversion of the penial gland (pg) of the pale slug, fortuitously everting onto a bubble rather than the dark slug; 1 - secretion (se) left behind on the bubble by the partially retracted penial gland; $\mathrm{m}, \mathrm{n}$ - writhing of mantles and copious mucus production giving the impression of melting together (particularly in specimens more similar in coloration); $\mathrm{m}$ - retraction of the penial caecum reveals a small part of the sperm mass $(\mathrm{sm})$ that it has deposited stuck to the sarcobelum 
which branches off from near the origin of the penial caecum (Fig. 7g, h). This finger has a fat balloon-like structure, much larger than in the tramp species and differing also in having a curious prickly dorsal surface rather than a smooth one (Fig. 7i, j). In $D$. panormitanum, the penial lobe is directed backwards towards the individual's own sarcobelum (cf. the Sardinian population of the tramp species) so that its only points of contact with the partner are base to base with the same structure of the partner and distally over part of the partner's extended caecum. By the time the penial lobe is fully everted, the penial caecum is already retracting.

In couples killed at the stage of maximal lobe eversion, the lobe covers the received ejaculate. The videos do not reveal any ejaculate at this position; it must have been deposited by and under the penial caecum. Maybe the penial lobe has a role in holding the ejaculate in place. The alternative explanation for the presence of sperm under the penial lobe, that the lobe applies sperm to the partner's caecum, must be rejected because in a pair fixed immediately prior to copulation autosperm had accumulated only in the penial caecum, not in the lobe (Fig. 5b). Between the underside of the penial lobe and the sperm is a small plate of secretion (Fig. 5e, f); it was also found in the lobe of some specimens killed prior to copulation. Most of the ejaculate lies on the glandular field on the recipient's penis (Fig. 5c, d); the attachment seems very firm, so we suspect that the skin structure or a glue produced by the glandular field serves a role in attaching the sperm. The flap at the margin of the glandular field flanks the received ejaculate (Fig. 5c).

As the penial lobe shrinks, a third projection everts from near the base of the retracted penial caecum (Fig. 7k). This projection is directed forwards and downwards and from it the fingers of the appending penial gland evert. Initially these fingers often shoot out sideways into free space before falling over the mantle of the partner. They appear a median of $13 \mathrm{~s}$ after the start of copulation, and the partners are fairly synchronous (median difference $=3 \mathrm{~s}$ ). Figure 71 shows that in this species, as in the tramp (BENKE et al. 2010), the gland deposits a secretion.

As the glands retract, and only the sarcobela remain extended, the partners continue to press against each other and the heads may rear up again and rub rhythmically against each other, with the mantle rocking side to side (Fig. $7 \mathrm{~m}, \mathrm{n}$ ). They produce so much mucus that the remarkable appearance is of the two bodies melting together. Even after both sarcobela retract (median $48 \mathrm{~s}$ after the start of copulation; quartiles: $38,60 \mathrm{~s}$ ) the rubbing continues, but it eventually diminishes, the heads are redirected, the tentacles emerge (for the slower partner a median of 137 $\mathrm{s}$ after the start of copulation), and the individuals separate. Individuals may eat mucus off their own bodies and off the ground.
Two intraspecific matings between D. panormitanum led to only one partner everting its penis. In both cases the partner that did not evert probably received a sperm mass onto its protruded sarcobelum. At least in one case, the recipient bent back and ate all or some of this ejaculate from its sarcobelum.

\section{Deroceras golcheri}

Our mating data are based on 11 couples (involving 16 individuals from altogether four sites) that showed some mating behaviour, 10 of which continued to courtship, and 9 copulated.

The precourtship and courtship of D. golcheri can show all the patterns shown by D. panormitanum (up until attempts at copulation start). Nevertheless, some aspects tend to differ. The tail is only slightly enlarged and is flattened merely at the dorsal and posterior margin. Rather than the bodies sliding past in contact with each other, in $D$. golcheri the bodies pass alongside but usually not touching, except via the sarcobela. The sarcobelum tends to be stroked backwards and forwards over the partner's flank (whereas in D. panormitanum more often the sarcobelum is dragged over the partner by the forward movement of the bodies). The sarcobela often are placed in contact posterior side to posterior side. And, particularly later in courtship, the tails are more bent to the right, so that the arrangement begins to resemble a yin-yang configuration rather than the antiparallel configuration of D. panormitanum. The median courtship duration was $164 \mathrm{~min}(N=6$, range 128-279 min, typically at $19^{\circ} \mathrm{C}$ ), which is longer than in $D$. panormitanum.

Towards the end of courtship the base of the sarcobelum swells up making it noticeably more bulbous than earlier in courtship. The position required for copulation is the two sarcobela bases pushing against each other front-to-front; this can take many minutes and numerous attempts to achieve. Copulation is not preceded by any rearing up or mouth-tomouth contact but the mouths are applied to the base of the partner's sarcobelum (Fig. 8b). The bases swell still further at the point of contact, which is the gradual start of penis eversion. At this stage the heads twist forward around this point of contact: as a consequence the sarcobela move like the hands of a clock, almost half a turn (Fig. 8c, d). We take the start of this rotation as a convenient origin to time the other events in the copulation; timings below are medians $(N=7)$.

Copulation starts off as a much slower process than in D. panormitanum. Each everting penis remains pressed alongside that of the partner as it develops into a straight tube (Fig. 8d) with its tip reaching forward to a point on the partner's expanded sarcobelum base where the sperm will be deposited. Having reached this point (at $6 \mathrm{~s}$ ), it flattens into a broad flap, everting further in two directions (Fig. 8e). One extension is a rightwards-directed lobe-like expansion 
of the flap over the flap of the partner (Fig. 8f); it looks that the sperm is deposited under the main flap prior to the full extension of this lobe-like extension (at $16 \mathrm{~s}$ ). The other extension is a narrow tubular branch that doubles sharply back to the left (Fig. 8e). From the end of this branch the penial gland everts over the mantle and right flank of the partner (appearing after a median of $11 \mathrm{~s}$, sometimes closely syn- chronised, sometimes not; Fig. 8g). In a minority of individuals this branch appears to be missing and the gland fingers insert directly onto the everted part of the penis. Most of the eversion of the gland takes place after the rest of the penes have started to contract and slip apart, revealing the deposited sperm mass. Penis-to-penis contact is lost at $47 \mathrm{~s}$ (quartiles: $38,52 \mathrm{~s}$ ). At this stage the mantle shows a side-to-side
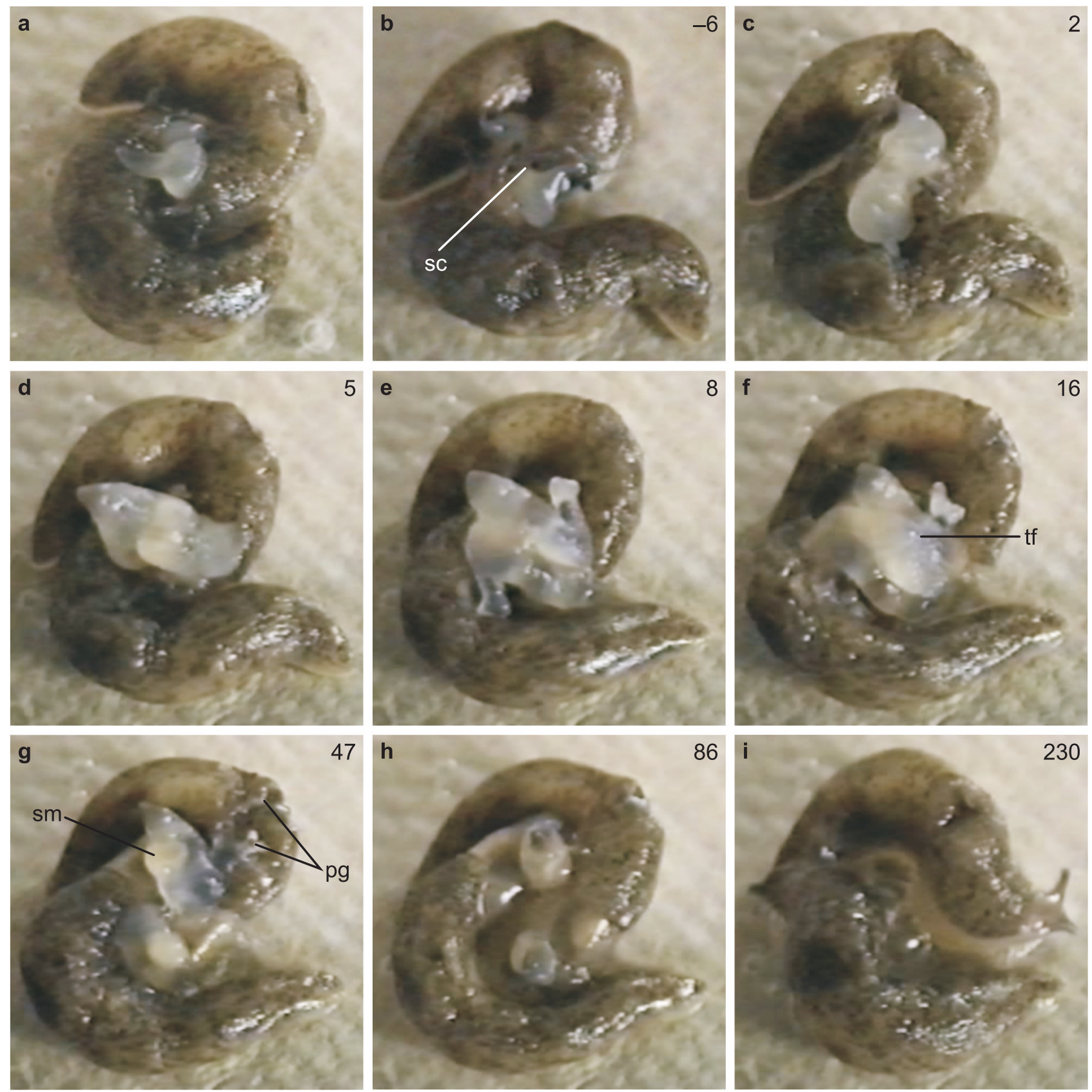

Fig. 8. Video-stills of a mating pair of Deroceras golcheri from site M6 (type locality). Figures at the top right are the time (s) relative to the start of rotation of the sarcobela: a - courtship $16 \mathrm{~min}$ before copulation; $\mathrm{b}$ - the bases of the sarcobela contact at the point indicated (sc); c - the penes start to evert and the sarcobela to turn clockwise; $d$ - the sarcobela have rotated a quarter turn (The tip of the everting penis reaches the site on the partner's sarcobelum base where sperm will be deposited.); e - one branch of the penis hooks back, but is yet to produce the penial gland; $\mathrm{f}$ - the other, flap-like extension of the penis covers the partner's penis (tf - tip of the lobe of the flap); $\mathrm{g}$ - the penes have separated, revealing the sperm masses $(\mathrm{sm})$, the penial gland $(\mathrm{pg})$ is fully extended over the partner; $\mathrm{h}-$ only the sarcobela remain extended; $\mathrm{i}$ - the partners crawl away 
oscillation reminiscent of that in D. panormitanum, but in $D$. golcheri there is no appearance of melting together; also different is that the heads and necks lie side to side on the ground, with the yin-yang configuration maintained (Fig. 8g). After the penial glands are retracted (disappearing at $71 \mathrm{~s}$ ), the sarcobela follow (disappearing at $90 \mathrm{~s}$ ), whereupon the tentacles emerge (later one at $114 \mathrm{~s}$ ) and the animals crawl apart. Sometimes the tentacles emerge before the sarcobelum has disappeared.

Interspecific matings

\section{D. golcheri $\times$ D. panormitanum}

We set up 23 couples (both species from Malta). Of these, $70 \%$ showed trail following. This is similar to figures of $65 \%$ and $73 \%$ for intraspecific D. golcheri and $D$. panormitanum couples. Nine interspecific couples courted, a rate of $40 \%$ (cf. $59 \%$ and $70 \%$ for the intraspecific pairs: n.s. different compared to $D$. golcheri). One courtship stopped after c. 29 min but in the other 8 couples the $D$. panormitanum everted unilaterally. This occurred after a median of $135 \mathrm{~min}$ of courtship (range: 89-209 min), so longer than usual for either species from Malta, no doubt because they tried but failed numerous times to assume a position that stimulated penis eversion. In two cases the $D$. golcheri received the sperm mass on the base of its sarcobelum; we did not see whether the sperm was taken in when the sarcobelum retracted. In three of the other six couples, we observed that sperm was not transferred onto the sarcobelum of D. golcheri.

\section{Species $\mathrm{X} \times D$. panormitanum}

Two specimens of species $\mathrm{X}$ from different localities were put with specimens of D. panormitanum from Sicily. One courted once, the other courted two times with different individuals. In all three cases the outcome was a unilateral eversion of the $D$. panormitanum penis, but not that of species $\mathrm{X}$. This was after courtships of 191, 294 and $428 \mathrm{~min}$, much longer than a normal courtship of D. panormitanum. During much of the courtships the partners made many attempts head-to-head to get into a position to trigger penis eversion. In one case the penial caecum of the D. panormitanum succeeded in wrapping round the sarcobelum of the species $\mathrm{X}$ and sperm was clearly deposited onto the base of the sarcobelum. This sarcobelum retracted only $6 \mathrm{~min}$ after the deposition of the sperm, but just prior to retraction the species $\mathrm{X}$ slug reached round and ate the sperm mass off its sarcobelum base. We cannot tell whether all was removed.

\section{Tramp species $\times D$. panormitanum}

We set up 13 pairings between $D$. panormitanum from Sicily and the tramp species from England (site E1); 11 showed precourtship behaviour, 7 courted, and 6 pairs attempted copulation. However, in two of these attempted copulations only one individual everted its penis (once one species, once the other). We also set up 24 pairings between $D$. panormitanum from Malta and the tramp species from England (site E1) and Antwerp (Belgium). Only three pairings led to courtship (the animals were probably getting too old to mate); two of these led to copulations in which both penes everted.

The length of courtship was a median of $88 \mathrm{~min}$ (range: 60-133 $\mathrm{min}$ ), so no longer than in the intraspecific matings. Typically at copulation the penial caecum of D. panormitanum succeeded in hooking round the sarcobelum of the tramp species and transferred sperm; the site of attachment was typical for the donor D. panormitanum rather than for the recipient species. The penial caecum of the tramp species reached its full eversion 3-6 s later (as expected from the relative speeds of this part of same-species copulations) and in no matings contacted the partner properly, coiling round itself instead. In four matings in which both species everted, the tramp partner was killed 15 min after the end of copulation and had sperm in the entrance to its penis. Following the two ejaculates on the videos is difficult, but it looks most likely in three of these cases that the tramp species took up the allosperm, leaving its autosperm on the ground.

\section{DNA SEQUENCES}

The 38 sequences contained 25 distinct haplotypes. Out of 656 sites, 206 varied (181 excluding the outgroup), of which 162 were parsimony informative.

Both the maximum-likelihood and Bayesian COI trees grouped individuals in agreement with our species delineations based on mating behaviour and genital anatomy. Figure 9 shows only the Bayesian tree because this resolves with greater confidence the interspecific relationships, some of which appear as polytomies in the ML tree (they never conflict topologically).

In both trees $D$. reticulatum branches off first from the other Deroceras. This finding prompted us to repeat the Bayesian analysis using $D$. reticulatum as the outgroup (omitting L. maximus). The resulting tree had higher credibilities (posterior probabilities) than in Fig. 9 but was very similar topologically except for the placement of $D$. cf. panormitanum from Crete. In both trees its placement has a low credibility $(p=0.54$, 0.57 ), so it is best to consider a trichotomy of (1) D. cf. panormitanum, (2) the tramp species, and (3) D. panormitanum plus D. golcheri plus species X.

Seven D. panormitanum, including individuals from both Malta and Sicily did not differ in COI sequence. The most divergent of the other three $D$. panormitanum differs from its conspecifics by $\leq 4 \%$; animals from its locality (Valletta on Malta) showed morphology and mating behaviour typical of this species. 
The three D. golcheri from Malta and Gozo cluster together (differing by a mean of $1.7 \%$ ). The surprise is that they fall within a group consisting of just $D$. golcheri and the two species $\mathrm{X}$ individuals from Sicily $($ credibility $=0.96)$. The two species $\mathrm{X}$ individuals dif- fer from $D$. golcheri individuals by a mean of $5.6 \%$. This group of five individuals is the sister group of $D$. panormitanum from the same islands (credibility = 0.99 ); individuals of one group differ from those of the other by a mean of $7.9 \%$.

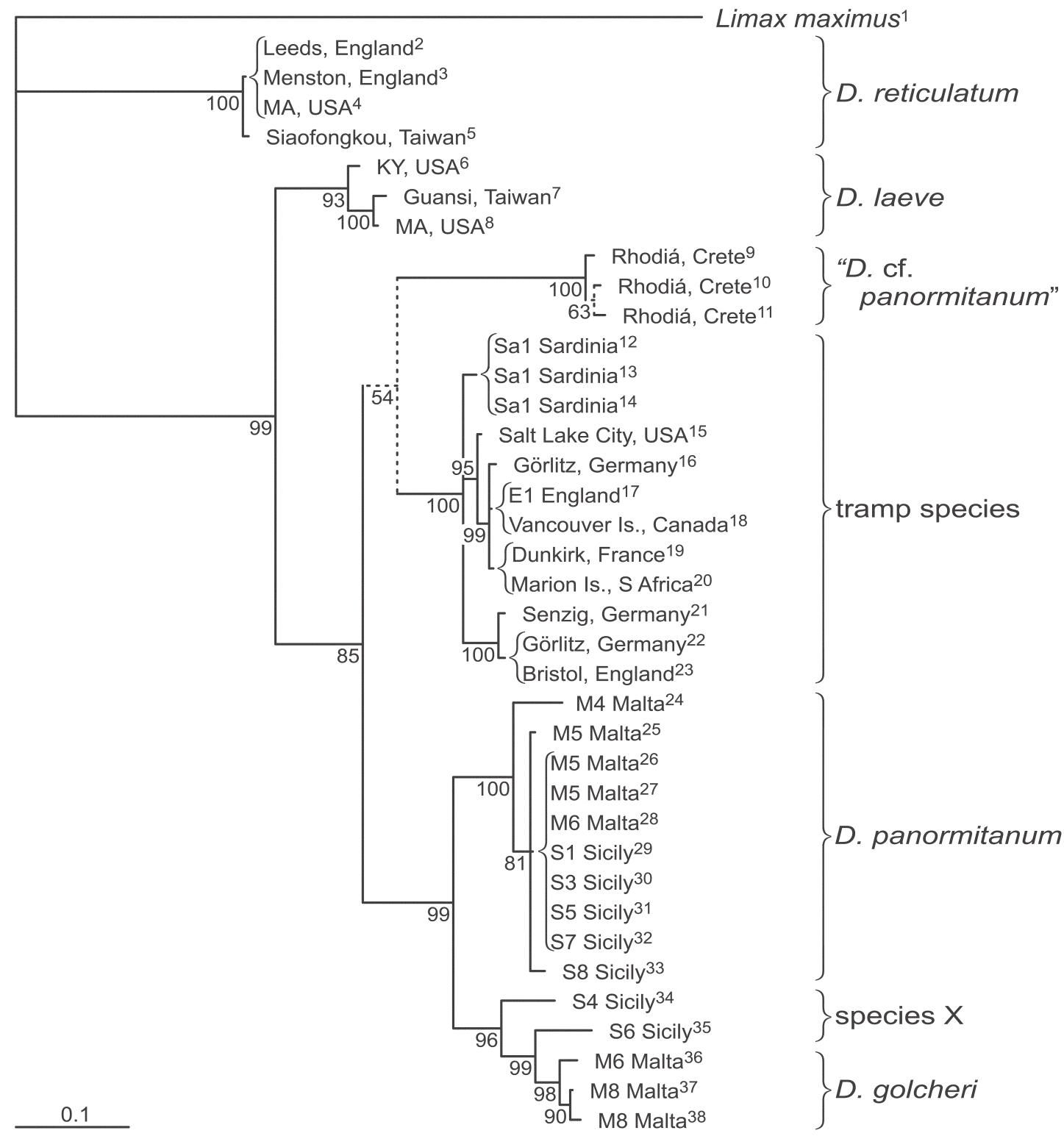

Fig. 9. Phylogenetic tree fitted by the program MrBayes to sequence data from $656 \mathrm{bp}$ region of the COI mitochondrial gene from Deroceras species (with Limax maximus as the outgroup). Left braces link individuals not differing in sequence. Figures at each branching report the percentage "credibility" (posterior probability) of the grouping: broken lines emphasise the two cases where these probabilities are low. The horizontal axis represents branch lengths, measured as expected substitutions per site. For each specimen (indexed by the suffix following the locality name), we list (where available and not already given in Table 1): latitude and longitude, our SMNG catalogue number, and GenBank accession number. 1: 51 ${ }^{\circ} 13^{\prime} 58^{\prime \prime N} 14^{\circ} 36^{\prime} 02 " \mathrm{E}$, p16308, JN248294; 2: AM259703; 3: AM259702; 4: AF239734; 5: FJ481179; 6: HM584699; 7: EF128217; 8: AF239733; 9-11: 3522'14"N, 2501'04"E, 9: p16931; 10: p16929; 11: p16930; 12: p16924, JN248298; 13: p16925, JN248299; 14: p16926, JN248300; 15: 4046'39"N, $111^{\circ} 53^{\prime} 06 " \mathrm{~W}, \mathrm{p} 16928$, JN248315;

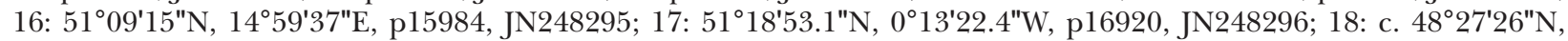

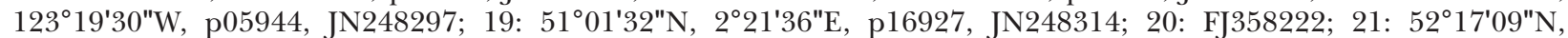

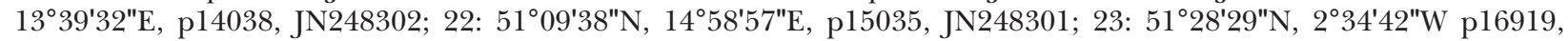
JN248303; 24: p16799, JN248311; 25: p16802, JN248309; 26: p16801, JN248308; 27: p16800, JN248307; 28: p16798, JN248310; 29: p16933, JN248304; 30: p16934, JN248305; 31: p16822, JN248306; 32: p16935, JN248312; 33: p16936, JN248313; 34: p16932; 35: p16815; 36: p16797, JN248291; 37: p16795, JN248292; 38: p16796, JN248293 
The mean difference between individuals of the tramp species was $3.0 \%$; the individuals from Sardinia, which differed slightly in mating behaviour, were not especially divergent in sequence. Unlike the other Deroceras species run in this study, all 12 individuals of this species show an amino-acid substitution of isoleucine for valine 40 codons downstream from the primer. (Otherwise the only amino-acid substitutions in this data set are three characteristic of all four $D$. reticulatum, and four different single-codon differences each in a different individual).

\section{DISCUSSION}

The morphology, mating behaviour and COI gene nucleotide sequences consistently show that we have dealt with three distinct species (D. golcheri, D. panormitanum and the tramp species), and maybe a fourth species (species X) closely related to $D$. golcheri. On Malta there were two species, D. golcheri and $D$. panormitanum, both widespread and sometimes cooccurring. Deroceras panormitanum from Malta and Sicily are indistinguishable. Sardinian specimens of the tramp species differed slightly in post sperm exchange mating behaviour from English specimens but their COI sequence firmly clusters them with all specimens from elsewhere sharing the tramp-species morphology.

In the species studied, as in many other species groups of Deroceras, it is difficult to decide whether the variation in the genitalia represents intraspecific or interspecific variation. Mating behaviour proved useful because it revealed clearly distinct mating types, which must indicate significant reproductive isolation and thus species boundaries. Now we can reassess the taxonomic value of the morphological characters considered previously. For example, the development of the penial lobe has previously been considered important (e.g. GIUSTI 1973, 1976), but we found that much of the variation was intraspecific within $D$. panormitanum. Observations of mating behaviour supported this conclusion in an additional way by revealing that the variation in preserved specimens was much greater than that when the lobe was in use, so that the variation was no barrier to successful mating. The penial caecum provides another example of the mismatch between morphology of the genitalia at rest and when in use (see HUTCHINSON \& REISE 2009 for further such examples in another pair of Deroceras species). The retracted penial caecum is relatively more prominent in the tramp species than in $D$. panormitanum, but it is the opposite during copulation: it is not even clear whether it is functional in the tramp species. This does not prevent its shape when retracted being a useful identifying character.

Although mating behaviour provided excellent characters with which to recognise species boundaries, it is unclear whether it provides characters useful for reconstructing a phylogeny. It could instead be that it evolves too quickly or exhibits too much convergence. In our species, the start of copulation indicated a closer relationship of $D$. panormitanum to the tramp species, and this was the only intraspecific cross in which the penes everted synchronously; but the courtship and the mantle rocking late in copulation suggested greater affinity between $D$. panormitanum and D. golcheri, as supported by the COI sequences. The pattern of waving sarcobela head to head, then sliding past each other to swap positions is also shown by Deroceras gorgonium Wiktor, Vardinoyannis and Mylonas, 1994 from Crete (REISE et al. 2007), but we have no data on COI from this species to assess whether this is because the species are closely related or because of convergence.

The species tested readily courted one another. Interspecific courtship is known between other species of Deroceras (HUTCHINSON \& REISE 2009). What is novel to this study is interspecific sperm transfer in Deroceras: D. panormitanum attached sperm to the sarcobela of $D$. golcheri, species X and to the tramp species. The very rapid eversion of the penial caecum and its application around the base of the sarcobelum are traits that facilitate such unilateral sperm donation. We wonder whether these traits evolved as adaptations for forced fertilisation of same-species partners that are not yet ready to donate their own sperm; we did observe two unilateral copulations within pairs of $D$. panormitanum. WIWEGWEAW et al. (2009) provided another example of interspecific sperm transfer in a terrestrial pulmonate and again this was predominantly unilateral with the donor being the faster species.

\section{DEROCERAS GOLCHERI AND SPECIES X}

Although the COI gene nucleotide sequences indicate a close relationship between $D$. golcheri and D. panormitanum they clearly differ in morphology and in copulation behaviour. They occur syntopically and may court with one another but this never leads to mutual eversion of the penes.

Deroceras panormitanum is widespread on both Sicily and Malta. Its occurrences include synanthropic sites, so recent transfer from one island to the other by man is conceivable. It is suggestive that GIUSTI (1986) reported $D$. panormitanum to be the rarer species on Malta, opposite to what we and GIUSTI et al. (1995) found subsequently. However, fossil evidence points to repeated bouts of faunal exchange between Sicily and Malta over the Quaternary (HUNT \& SCHEMBRI 1999), quite possibly associated with land bridges, so 
the natural occurrence of $D$. panormitanum on both islands seems equally plausible.

If $D$. panormitanum can spread between the two islands, why has $D$. golcheri not been found on Sicily? One answer might be that $D$. golcheri is the Maltese vicariant of a species that on Sicily we have called species X. The COI sequences indicate a close relationship and there are morphological similarities (e.g. lack of a prominent penial caecum or lobe). But there are also morphological differences; these are hard to assess without more data on the variability of species $\mathrm{X}$. Knowledge of its mating behaviour and ability to mate with $D$. golcheri would also help to decide whether we should call these two species or one. Other populations to be compared with $D$. golcheri are slugs from the islands of Montecristo (near Elba: Fig. 1) (GIUSTI 1976) and Corsica (WIKTOR 2000, Fig. 267) that are morphologically similar to $D$. golcheri and populations from the Italian mainland and Elba considered as the cecconii or cecconii var. ilvatica morphs of D. panormitanum (GIUSTI 1976).

Species $\mathrm{X}$ seems rarer on Sicily than D. panormitanum. Three independent collectors provided us with numerous $D$. panormitanum from altogether at least five localities on Sicily but only two single specimen of species X. In addition, GIUSTI provided us with five samples from Sicily with mature specimens: four contained D. panormitanum and one (from Niscemi) had specimens reminiscent of $D$. golcheri or species X. The tramp species appears to be even rarer: we received only one specimen from Sicily.

\section{DEROCERAS PANORMITANUM}

There has been much debate whether $D$. caruanae and $D$. pollonerae should be considered as junior synonyms of D. panormitanum (VAN GOETHEM \& DE WILDE 1984, GIUSTI 1986, GIUSTI \& MANGANELLI 1990). Much of this debate has been based entirely on different interpretations of the original species descriptions. At the time of these descriptions body size and coloration were considered as important distinctive characters, while modern workers distrust them (e.g. WIKTOR 2000), but the descriptions do also deal with penis morphology. The species descriptions and genital drawings of $D$. pollonerae and $D$. caruanae clearly indicate the presence of two penial pockets (the penial lobe and penial caecum). In contrast, the description of $D$. panormitanum implies that one of the pockets (the lobe) might be reduced or absent: the species description does not mention a second pocket, and the drawing implies not more than a swelling (though a reduced pocket might be hidden). However, the length of the penial lobe appears not to be a very informative taxonomic character. Our material from Sicily and Malta shows considerable variability, ranging from a long pocket (similar to the tramp) to so strongly reduced that it is hardly perceptible as a pocket (Fig. 2). Such specimens having a spherical penis with a scarcely distinguishable proximal part of the penis (Fig. 2k-m) fit the original description of $D$. panormitanum.

All three original descriptions and drawings are poor, and none make a comparison with the other species descriptions, but the impression given is that also the shape of the penial caecum might differ between these taxa. The description of $D$. pollonerae is the least ambiguous in referring to the same species as our material. SimRoth (1889) describes one pocket as long, slim and rather bent and the other pocket as wide and short. The species description of D. panormitanum also shows a caecum that is long, pointed and bent and only slightly thicker than the fingers of the appending penial gland.

In contrast, the penial caecum of $D$. caruanae was described as large, elongated, curved and rounded, and the drawing implies a blunt non-tapering structure (POLLONERA 1891). This sounds more like the tramp species than $D$. panormitanum. However, although no type specimens of any of these taxa survive, there are two specimens probably from the same sample as the holotype of $D$. caruanae (ALTENA 1962), one designated as a neotype (GIUSTI \& MANGANELLI 1990). These specimens are missing (R. JANSSEN pers. com.) but their description indicates the same characters as in D. panormitanum and in our specimens from Malta: they are described as having a pointed caecum; the neotype's caecum looks rather short but the other's caecum is longer (GiUsti \& MANGANelli 1990). Besides, Malta has been well studied and none of the extensive material looks like the tramp species. The description of $D$. caruanae surely cannot apply to the only other Deroceras known from Malta, D. golcheri. So we conclude that the apparent discrepancy with the other two species descriptions reflects a weakness of POLLONERA's (1891) species description.

$D$. pollonerae and D. caruanae have long been considered as synonyms (GIUSTI 1973, 1976), because they both have two pockets. GIUSTI \& MANGANELLI (1990) and GIUSTI et al. (1995) also synonymised them with $D$. panormitanum. In the absence of any reliable characters suggesting otherwise, we also conclude that the three taxa are synonymous.

Most authors have accepted the synonymy of $D$. panormitanum, D. pollonerae and D. caruanae. The most opposing opinion came from VAN GOETHEM \& DE WILDE (1984) who considered all three species as valid. These authors had faith in many details from the figures of the original descriptions, whilst we question whether these descriptions are sufficiently trustworthy. They used distinguishing characters which show too much intraspecific variability to be taxonomically informative (GIUSTI 1986). They had apparently not investigated specimens from Malta and possibly nor from Sicily (although an addendum 
mentions "some preserved slugs from different localities" from GIUSTI) and, very importantly, seem to have used the tramp species as representative of $D$. caruanae: they write that they had investigated hundreds of specimens of this species, which seems highly unlikely otherwise. At least some of their characters for D. caruanae are clearly based on the tramp species: the shape and length of the penial pockets and the insertion, shape and length of the appending penial gland fingers.

We propose that a fourth species name Deroceras giustianum, is also synonymous. This was described by WIKTOR (1998) from one locality in NW Sicily. We have examined the two adult type specimens. The penis morphology, particularly the long pointed caecum, fits very well the description of D. panormitanum and our specimens, and it shares the distinctive flap inside its penis. This flap is bigger than the one in Fig. $4 \mathrm{~b}$, but we assume that this is within the range of this species. This seems also to be the case with the unusually long base of the appending penial gland because the illustration of a paratype implies that its base is considerably shorter. WIKTOR's (1998) illustrations show penes that lack a clear lobe and are undivided into distal and proximal part but our Figs 2a, $\mathrm{k}-\mathrm{m}$ show that $D$. panormitanum may look like this. The only clear difference is the body colour (blackish), but this is usually not a reliable species character in Deroceras. The holotype is now grey (it might have faded) and looks externally like our specimens from Sicily locality S5. WIKTOR (1998) seems not to have considered the possibility of conspecificity with $D$. panormitanum, possibly because he was considering specimens of the tramp species as representative of D. panormitanum. That WIKTOR (1998) might not have been acquainted with Sicilian D. panormitanum is supported by the fact that he considered $D$. giustianum as a possible synonym of Deroceras dubium (Hoffmann, 1941) (WIKTOR 2000). GIUSTI (1973) has convincingly shown that $D$. dubium is a synonym of $D$. pollonerae and thus of $D$. panormitanum.

The above conclusions are based entirely on material from Sicily and Malta, either the original descriptions or material available to us. Clearly much of the material from elsewhere is the tramp species, but GIUSTI (1973, 1976) also examined material from many sites in Italy that require more careful consideration. He considered specimens with the penial caecum and lobe both well developed as the pollonerae morph of D. panormitanum and those with a caecum but a strongly reduced lobe as the panormitanum morph of $D$. panormitanum. The morphological characters that we consider as taxonomically informative (shape of the caecum, insertion of penial retractor, appending penial gland and vas deferens, presence of flap, and size and position of glandular field inside the penis, but not the size of the penial lobe) were apparently not considered. For example, GIUSTI (1973) found specimens on the Eolian Islands which have a caecum in the shape typical of the tramp species and a partly or fully reduced penial lobe. Due to the missing lobe they were considered as the panormitanum morph. GIUSTI has kindly lent us some of these specimens, and we do not think that they are conspecific with $D$. panormitanum, because the shape of the caecum is different and because they do not have the flap. Whether a reduction of the penial lobe is within the range of variability of the tramp species or whether these slugs represent a distinct species remains to be investigated. The inclusion of these and similar forms, and even of specimens with both caecum and lobe considerably reduced (D. cecconii and D. cecconii var. ilvatica), has surely contributed to the confusion around $D$. panormitanum s.l. and led to the conclusion that this species has an exceptionally high morphological variability (WIKTOR 2000).

\section{THE TRAMP SPECIES}

All data show that the tramp species is distinct from D. panormitanum. Previously, the only explicit suggestion that the tramp species might be none of $D$. caruanae, D. pollonerae or D. panormitanum (FORCART 1960) was based on an unreliable character (PILSBRY's (1948) second-hand claim that the tramp species has a long neck).

Although we identified one specimen of the tramp species from Sicily (from a lettuce on a market, but apparently locally grown), there is no evidence for the usual assumption that Sicily or Malta is its original home (KERNEY 1999, WIKTOR 2000). Despite its rapid colonisation of the world, specimens from introduced populations retain reasonable genetic diversity and we found variation even within the town of Görlitz, where we know that it is a recent arrival (REISE \& BACKELJAU 1994, cf. LEE et al. 2009 who found only one haplotype amongst 25 individuals on Marion Island). But if higher genetic diversity is found elsewhere this may indicate its origin. We still suspect a Mediterranean origin somewhere around Italy. The reason is that GIUSTI $(1973,1976)$ described several populations from the Italian mainland, the Tuscan islands and Eolian Islands that morphologically are reminiscent of, but at least not always congruent with, the tramp species. These populations require further investigations involving non-morphological characters.

The question remains what to call the tramp species. We have already ruled out $D$. panormitanum, $D$. pollonerae, D. caruanae, D. giustianum and D. dubium. We consider now other species that have been considered as synonyms of $D$. panormitanum. Deroceras cecconii (Pollonera, 1896) has been proposed as a synonym (GIUSTI 1973, 1976, WIKTOR 2000) but the description (POLLONERA 1896) does not show or mention any penial pocket, except a hump, so it seems un- 
related. Deroceras cecconii var. ilvatica was described by POLLONERA (1905) as even more similar to "Agriolimax agrestis" (=D. reticulatum). GIUSTI (1976) interpreted this taxon as having a single large pocket and as also a synonym of $D$. panormitanum, but his illustrations do not suggest to us either the true $D$. panormitanum or the tramp species. BISHOP (1980) proposed Agriolimax scharffi Simroth, 1910 as another synonym, but the original description (SIMROTH 1910) ignores the anatomy, so it is impossible to say to which of the species around the type locality it applies (BODON et al. 1982). WIKTOR (2000) interpreted Deroceras dallai Giusti, 1970 as a possible synonym of $D$. panormitanum, but our collections from the type locality prove it to be a very distinct species (HUTCHINSON \& REISE unpublished).

AltenA \& SMITH (1975) tentatively suggested that Limax queenslandicus Hedley, 1888 was a synonym of the tramp species despite HEDLEY's later belief that $L$. queenslandicus was a synonym of D. laeve (PILSBRY 1891). There is no record of the type specimens that HEDLEY (1888) claimed to have deposited in the Queensland Museum (D. POTTER pers. com.) and his description could fit D. laeve or the tramp species (the length of $30 \mathrm{~mm}$ is long, though not impossible, for $D$. laeve). ALTENA \& SMITH (1975) proposed their synonymy because they had found the tramp species but no D. laeve in extensive material from Australia. The type locality is in Queensland, Australia, not far from its southern border with New South Wales. Deroceras laeve has since been reported from New South Wales but still not in Queensland (STANISIC et al. 2010, D. POTTER pers. com.).

However, we have discovered that D. laeve was indeed present in Queensland when L. queenslandicus was described. HEYNEMANN (1885) gives Burnet River, Queensland as a locality for Limax rarotonganus; this is a synonym for $D$. laeve, and we confirm that specimens in the Senckenberg Museum of Natural History Frankfurt labelled as this species from Queensland in 1885 and derived from HEYNEMANN's collection are indeed $D$. laeve. Furthermore, SIMROTH (1889) reported that he had received four specimens of L. queenslandicus from HEDLEY that he recognised as $D$. laeve. If they had been the tramp species he would certainly have identified them as $D$. pollonerae (the synonym of D. panormitanum), which he described in the same paper. And his anatomical description of these specimens leaves no doubt that this is not the tramp species but most probably D. laeve.

Lastly we come to Deroceras meridionale Reygrobellet, 1963 described from southern France. Although the description and illustrations are poor by modern standards, and there is no mention of a type specimen or locality, they clearly apply to the tramp species. However, ALTENA (1966) pointed out that the name is a junior secondary homonym of Agriolimax meridionalis Doering, 1874 (= D. laeve). Although the senior homonym has scarcely been used, nor has the junior homonym, so there are no grounds for reversing the precedence (ICZN Article 23.9). In the absence of any further synonyms, it must be replaced by a new substitute name (ICZN Article 60.3). So we now formally redescribe the species under the new name Deroceras invadens.

\section{Deroceras invadens n. sp.}

Deroceras (Agriolimax) panormitanum (nec. sensu Lessona et Pollonera, 1882): KERNEY \& CAMERON 1979, CASTILlejO 1998, BARKER 1999, FORSYTH 2004, REISE 2007.

Deroceras (Agriolimax) pollonerae (nec. sensu Simroth, 1889): LIKHAREV \& WIKTOR 1980.

Deroceras (Agriolimax) caruanae (nec. sensu Pollonera, 1891): PILSBRY 1948, QUICK 1960, SIRGEL 1973, Altena \& SMITH 1975.

Deroceras meridionale Reygrobellet, 1963: unavailable name, homonym of Agriolimax meridionalis Doering, 1874.

Agriolimax Scharffi Simroth, 1910: nomen dubium (insufficient description, type unavailable).

Holotypus. Nork Park, Banstead (Surrey, Great Britain, 51 $\left.{ }^{\circ} 18^{\prime} 53.1^{\prime \prime} \mathrm{N}, 0^{\circ} 13^{\prime} 22.4^{\prime \prime} \mathrm{W}\right)$, under litter and dead wood, leg. J. M. C. HutChinson, 23.01.2006, Senckenberg Museum of Natural History Görlitz no. p16551.

Paratypi. All from the same locality as the holotype, leg. J. M. C. HutChinson. 12 spec. collected with the holotype: 1 spec. Field Museum Chicago no. FMNH 328257, 11 spec. Senckenberg Museum of Natural History Görlitz nos. p16552-p16555. 30 spec. coll. 17.4.2011: 5 spec. Field Museum Chicago no. FMNH 328258, 5 spec. Natural History Museum London NHM no. 20110178, 5 spec. Museum of Natural History Wrocław no. MP 1010, 15 spec. Senckenberg Museum of Natural History Görlitz no. p16556.

Diagnosis. A medium-sized brownish slug, often with dark spotting that is less apparent in living slugs than in alcohol-preserved specimens. Proximal penis with two side pockets (the penial lobe and caecum) of roughly equal width and with stout, rounded tips. Retractor inserting between these pockets with some side branches leading from there to the penial lobe. Vas deferens and appending penial gland enter penis roughly midway between the pockets. Sarcobelum in the shape of a slightly flattened cone. Internal wall of distal penis with small glandular field near margin to proximal penis but no flap as present in $D$. panormitanum.

Body dimensions. Body length: living specimens usually c. 20-35 mm. The fully mature type specimens (preserved) 13-19 mm long and 3-5 mm wide, mantle shield more than a third of body length: $5.5-8 \mathrm{~mm}$.

External appearance. Living slugs appear very lively and aggressive, reacting to disturbance with in- 
tense tail lashing. Tail then flag-like, i.e. enlarged and flattened. This tail shape is also typical in alcoholpreserved specimens (DE WINTER 1988). Mucus colourless. Body wall thin and transparent.

Coloration pale greyish or creamish brown, chocolate brown, or blackish brown. Living slugs appear unicoloured, but on close inspection or particularly in alcohol-preserved specimens usually with dense dark spotting mainly on mantle but also on back and body sides; unspeckled field around pneumostome. There are also unspotted specimens (including from the type locality). Sole pale greyish cream. The brown body colour may fade considerably in preserved specimens, then appearing light cream with strongly contrasted dark spotting.

Anatomy. (Figs 3a-h, 4e). Only clear distinctive morphological characters provided by penis which consists of a distal and a proximal part. Distal part with sarcobelum in the shape of a slightly flattened cone. Penis wall at and around base of sarcobelum very glandular and thus very thick. On the wall inside near the margin to proximal penis is a glandular field which can be small and inconspicuous. Proximal penis with two side pockets of roughly equal width, smooth surface and rounded, stout ends. Appending penial gland inserting in gap between the side pockets. On a strong common base 3-7 (usually 4-6) long gland fingers, not or only slightly lobed, usually not branched. Vas deferens enters in the gap almost exactly midway between the penial pockets (only on close examination can be seen to insert towards base of caecum). Penial retractor inserting at proximal penis about midway between penial side pockets. From there some smaller branches lead to base of appending penial gland, to margin of distal penis, to penial lobe and to base of caecum. There is no flap inside the penis as in D. panormitanum. Glandula hermaphroditica usually underneath the rectum, usually much or all of it covered by digestive gland and diges-

\section{REFERENCES}

Altena C. O. van Regteren 1962. Notes sur les limaces, 6-7. 6. A propos des limaces de l'île de Malte. Basteria 26: $47-53$.

Altena C. O. VAn Regteren 1966. Notes on land slugs 11. Arionidae, Milacidae and Limacidae from South Africa (Mollusca, Gastropoda, Pulmonata). Zoöl. Meded. 41: 269-298.

Altena C. O. van Regteren, Smith B. J. 1975. Notes on introduced slugs of the families Limacidae and Milacidae in Australia, with two new records. J. Malac. Soc. Aust. 3: 63-80.

BARKER G. M. 1999. Naturalised terrestrial Stylommatophora (Mollusca: Gastropoda). Fauna of New Zealand No. 38. Manaaki Whenua Press, Canterbury, New Zealand. tive tract, but may also lay behind or in front of the rectum (as in Fig. $3 \mathrm{~h}$ ). Bursa copulatrix oval.

Intestinal caecum is a small widening of the rectum or entirely lacking.

Etymology. The name is derived from the Latin invadere, to invade, referring to the species' demonstrated ability to invade new areas all over the world.

\section{ACKNOWLEDGEMENTS}

How rude of us in a volume honouring the mighty corpus of work of ANDRZEJ WIKTOR to synonymise one of his species, D. giustianum! However, he has shown that he is not at all the sort of person to resent others casting out his ideas if they have the evidence. The sincerest form of praise of a scientist is for his students to build on his work. All slug workers the world over build on the work of ANDRZEJ WIKTOR and we personally have often benefitted from his generous and wise advice. Many thanks to THIERRY BACKELJAU (Antwerp/Brussels) for his detailed refereeing and advice as well as for providing specimens. We also thank ENRICO BELLIA and MAURICIO SARÀ (Palermo), JONATHAN ETZOLD (Greifswald), MICHAEL SCHLITT (Görlitz), and ULRICH SCHNEPPAT (Bündner Naturmuseum, Chur) for providing specimens. We are grateful to FOLCO GIUSTI for the loan of specimens and to the curators and collection managers of several museums who provided information or specimens for loan: Field Museum Chicago (JOCHEN GERBER), Senckenberg Natural History Museum Frankfurt (RONALD JANSSEN), Museum of Natural History Wrocław (BEATA POKRYSZKO and JOLANTA JURKOWSKA), Zoological Museum MIZ Warsaw (DOMINIKA MIERZWA-SZYMKOWIAK), Zoological Museum Berlin (MATTHIAS GLAUBRECHT and CHRISTINE ZORN), Queensland Museum (DARRYL POTTER). A part of the molecular study was supported by the Paul Ungerer Foundation (grant to HR \& JMCH).

Benke M., Reise H., Montagne-Wajer K., Koene J. 2010. Cutaneous application of an accessory-gland secretion after sperm exchange in a terrestrial slug (Mollusca: Pulmonata). Zoology 113: 118-124.

BISHOP M. J. 1980. The distribution of recent terrestrial molluscs in Piemonte and Valle d'Aosta. Atti Soc. ital. Sci. Milano 121: 201-210.

Bodon M., BoATO A., Giusti F. 1982. On the genus Deroceras in western Liguria, with description of a new species (Gastropoda: Derocerasidae). Animalia 9: 53-71.

CASTILlejo J. 1998. Guia de las babosas ibericas. Real Academia Galega de Ciencias, Santiago de Compostela.

Craze P. G., BARR A. G. 2002. The use of electrical-component freezing spray as a method of killing and preparing snails. J. Moll. Stud. 68: 191-192. 
DE WINTER A. J. 1988. Remarks on the non-marine molluscan fauna of the Azores. 1-2. Basteria 52: 105-109.

DVOŘÁK L., ČEJKA T., HORSÁK M. 2003. First record of Deroceras panormitanum (Gastropoda, Agriolimacidae) from Slovakia. Biologia 58: 917-918.

Folmer O., Black M., HoeH W., Lutz R., VRiJenHOeK R. 1994. DNA primers for amplification of mitochondrial cytochrome c oxidase subunit I from diverse metazoan invertebrates. Mol. Mar. Biol. Biotechnol. 3: 294-299.

FORCART L. 1960. Mollusken aus den Abruzzen mit taxonomischen Beschreibungen. Verh. Naturforsch. Ges. Basel 71: 125-139.

FORSYTH R. G. 2004. Land snails of British Columbia. Royal BC Museum, Victoria, Canada.

GIUSTI F. 1973. Notulae malacologicae XVIII. I molluschi terrestri e salmastri delle Isole Eolie. Lav. Soc. ital. Biogeogr. 3: 113-306.

GIUSTI F. 1976. Notulae malacologicae XXIII. I molluschi terrestri, salmastri e di acqua dolce dell'Elba, Giannutri e scogli minori dell'Arcipelago Toscano. Lav. Soc. ital. Biogeogr. 5: 99-355.

GIUSTI F. 1986. Notulae malacologicae, XXXIV. Again on the taxonomic status of Deroceras panormitanum (Lessona \& Pollonera, 1882), Deroceras pollonerai (Simroth, 1889) and Deroceras caruanai (Pollonera, 1891). Boll. Malacol. 22: 57-64.

GiUsti F., MANGANELli G. 1990. Notulae malacologicae, XLIV. A neotype for Agriolimax caruanae Pollonera 1891 (Pulmonata: Agriolimacidae). Arch. Moll. 119: 235-240.

Giusti F., Manganelli G., Schembri P. J. 1995. The non-marine molluscs of the Maltese Islands. Monografie XV, Museo Regionale di Scienze Naturali, Torino.

GUINDON S., GASCUEL O. 2003. A simple, fast and accurate method to estimate large phylogenies by maximum-likelihood. Syst. Biol. 52: 696-704.

Hedley C. 1888. Description of a new slug, with notes on other terrestrial Mollusca. Proc. Royal Soc. Queensland 5: 150-153, 1 pl.

HeYNEMANN D. F. 1885. Die nackten Landpulmonaten des Erdbodens. Jb. dt. Malakozool. Ges. 12: 236-330.

HORSÁK M., DVOŘÁK L. 2003. First records of the introduced slug Deroceras panormitanum (Lessona et Pollonera, 1882) from the Czech Republic (Mollusca: Gastropoda: Agriolimacidae). Folia Malacol. 11: 57-58.

HUELSENBECK J. P., RONQUIST F. 2001. MRBAYES: Bayesian inference of phylogenetic trees. Bioinformatics 17: 754-755.

HuNT C.O., SCHEMBRI P. J. 1999. Quaternary environments and biogeography of the Maltese Islands. In: MIFSUD A., SAVONA VENTURA C. (eds). Facets of Maltese prehistory, The Prehistoric Society of Malta, Malta, pp. 41-75.

Hutchinson J. M. C., REISE H. 2009. Mating behaviour clarifies the taxonomy of slug species defined by genital anatomy: the Deroceras rodnae complex in the Sächsische Schweiz and elsewhere. Mollusca 27: 183-200.

KERNEY M. 1999. Atlas of the land and freshwater molluscs of Britain and Ireland. Harley Books, Great Horkesley, Colchester.
Kerney M. P., CAMERon R. A. D. 1979. A field guide to the land snails of Britain and North-West Europe. Collins, London.

Lee J. E., Janion C., Marais E., Jansen van VuUren B., CHOwn S. L. 2009. Physiological tolerances account for range limits and abundance structure in an invasive slug. Proc. R. Soc. B 276: 1459-1468.

Lessona M., Pollonera C. 1882. Monografia dei limacidi italiani. Turin. (Reprinted 1884 in Mem. Accad. Sc. Torino, Ser. 2 35: 49-128).

LIKHAREV I. M., WIKTOR A. 1980. The fauna of the slugs of the USSR and adjacent countries (Gastropoda terrestria nuda). Fauna SSSR, Mollyuski, Vol. III, Part 5. Nauka, Leningrad. [In Russian].

PILSBRY H. A. 1891. Australian Limax. Nautilus 4: 107.

Pilsbry H. A. 1948. Land Mollusca of North America (North of Mexico). Vol. II, Part 2. Acad. Nat. Sci. Philadelphia Monogr. 3: 521-1113.

POllonera C. 1891. Appunti di malacologia. VII. Intorno ai Limacidi di Malta. Boll. Mus. Zool. Anat. Comp. R. Univ. Torino 6: 1-4.

POllonera C. 1896. Appunti di malacologia, IX-X. Sui limacidi di Corsica; un nuovo limacide della Toscana: Agriolimax cecconii n. sp. Boll. Mus. Zool. Anat. Comp. R. Univ. Torino 11: 1-6.

POLlonerA C. 1905. Note Malacologiche. II. Molluschi terrestri e fluviatili delle Isole d'Elba e Pianosa. Boll. Mus. Zool. Anat. Comp. R. Univ. Torino 20: 3-9.

POSADA D. 2008. jModelTest: phylogenetic model averaging. Mol. Biol. Evol. 25: 1253-1256.

QUick H. E. 1960. British slugs (Pulmonata: Testacellidae, Arionidae, Limacidae). Bull. Br. Mus. Nat. Hist. Zool. 6: 103-226.

REISE H. 2007. A review of mating behavior in slugs of the genus Deroceras (Pulmonata: Agriolimacidae). Amer. Malac. Bull. 23: 137-156.

REISE H., BACKELJAU T. 1994. Deroceras panormitanum (Lessona \& Pollonera, 1882), sensu Giusti, 1986 in Ostsachsen (Gastropoda, Stylommatophora, Agriolimacidae). Abh. Ber. Naturkundemus. Görlitz 68: 71-76.

Reise H., Hutchinson J. M. C., Robinson D. 2006. Two introduced pest slugs: Tandonia budapestensis new to the Americas, and Deroceras panormitanum new to the Eastern USA. Veliger 48: 110-115.

Reise H., Visser S., Hutchinson J. M. C. 2007. Mating behaviour in the terrestrial slug Deroceras gorgonium: is extreme morphology associated with extreme behaviour? Anim. Biol. 57: 197-215.

REYGROBELLET D. 1963. Une nouvelle espèce de limacidé, Deroceras meridionale n. sp. Bull. Soc. Zool. France 88: 399-402.

RoNQUist F., HUELSENBECK J. P. 2003. MrBayes 3: Bayesian phylogenetic inference under mixed models. Bioinformatics 19: 1572-1574.

SCHMidT H. A., STRIMMER K., Vingron M., VON HAESELER A. 2002. Tree-puzzle: maximum likelihood phylogenetic analysis using quartets and parallel computing. Bioinformatics 18: 502-504. 
SIMROTH H. 1889. Beiträge zur Kenntniss der Nacktschnecken. Nachr. Bl. dtsch. malak. Ges. 21: 177-186.

SimROTH H. 1910. Nacktschneckenstudien in den Südalpen. Abh. Senckenb. Naturf. Ges. 32: 275-348, plates 23-24.

SIRGEL W. 1973. Contributions to the morphology and histology of the genital system of the pulmonate Agriolimax caruanae. Ann. Univ. Stellenbosch Ser. A 48: 1-43.

Stanisic J., Shea M., POtTER D., GrifFiths O. 2010. Australian land snails Volume 1: A field guide to eastern Australian species. Bioculture Press, Mauritius.

VAN GOeTHEM J. L., DE WiLdE J. J. 1984. On the taxonomic status of Deroceras caruanae (Pollonera 1891) (Gastropoda: Pulmonata: Agriolimacidae). Arch. Moll. 115: 305-309.

WikTOR A. 1998. Two new for science Deroceras species from France and the Italian island of Sicily (Gastropoda: Pulmonata: Agriolimacidae). Malak. Abh. 19: 13-19.

WIKTOR A. 2000. Agriolimacidae (Gastropoda: Pulmonata) - a systematic monograph. Ann. Zool. 49: 347-590.
WIKTOR A. 2001a. Deroceras (Deroceras) panormitanum (Lessona et Pollonera, 1882) - a new introduced slug species in Poland (Gastropoda: Pulmonata: Agriolimacidae). Folia Malacol. 9: 155-157.

WikTOR A. 2001b. The Slugs of Greece (Arionidae, Milacidae, Limacidae, Agriolimacidae - Gastropoda, Stylommatophora). Fauna Graeciae VIII. Natural History Museum of Crete and Hellenic Zoological Society, Irakleio.

WINNEPENNINCKX B., BACKELJAU T., DE WACHTER R. 1993. Extraction of high molecular weight DNA from molluscs. Trends Genet. 9: 407.

WiWegWeaW A., KeIICHI S., MORI H., Asami T. 2009. Asymmetric reproductive isolation during simultaneous reciprocal mating in pulmonates. Biol. Lett. 5: 240-243.

Received: April 18th, 2011

Revised: July 15th, 2011

Accepted: July 16th, 2011 